University of Rhode Island

DigitalCommons@URI

Open Access Master's Theses

1991

\title{
THE PROVIDENCE WATERFRONT GUIDEPLAN
}

Bryant Mitchell Keith

University of Rhode Island

Follow this and additional works at: https://digitalcommons.uri.edu/theses

\section{Recommended Citation}

Keith, Bryant Mitchell, "THE PROVIDENCE WATERFRONT GUIDEPLAN" (1991). Open Access Master's

Theses. Paper 560.

https://digitalcommons.uri.edu/theses/560

This Thesis is brought to you for free and open access by DigitalCommons@URI. It has been accepted for inclusion in Open Access Master's Theses by an authorized administrator of DigitalCommons@URI. For more information, please contact digitalcommons-group@uri.edu. 
THE

PROVIDENCE WATERFRONT

GUIDEPLAN

\author{
BY \\ BRYANT MITCHELL KEITH
}

A RESEARCH PROJECT SUBMITTED IN

PARTIAL FULFILLMENT OF THE REQUIREMENTS

FOR THE DEGREE OF MASTER OF

COMMUNITY PLANNING

UNIVERSITY OF RHODE ISLAND

1991 


\section{Dedication}

This work is dedicated to my wife, Miriam, in humble recognition of her character and selfless support which made this effort possible. 


\section{Providence Waterfront Guideplan \\ TABLE OF CONTENTS}

Table of Contents $\ldots \ldots \ldots \ldots \ldots \ldots \ldots \ldots \ldots$

List of Figures $\ldots \ldots \ldots \ldots \ldots \ldots \ldots \ldots \ldots \ldots$ ii

List of Maps $\ldots \ldots \ldots \ldots \ldots \ldots \ldots \ldots \ldots \ldots \ldots \ldots \ldots$ iv

Chapter 1: INTRODUCTION ...............

1.1 Topic of Research $\ldots \ldots \ldots \ldots \ldots \ldots$

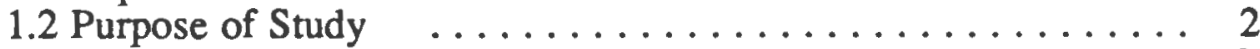

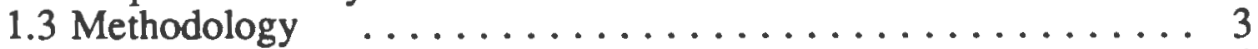

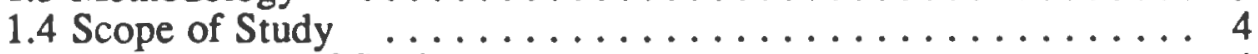

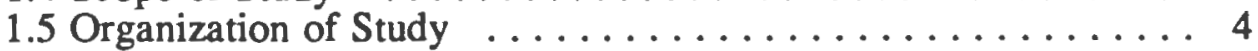

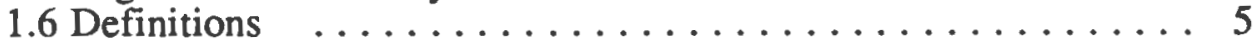

\section{Chapter 2: OVERVIEW OF PROVIDENCE WATERERONT STUDJES, Page 9}

2.1 Area \#1 - The Port of Providence Area .............. 9

2.2 Area \#2 - The Downtown Waterfront Area ............ . 19

1. The Old Harbor Section

2. The India Point/Fox Point Section

3. The Seekonk River Section

2.3 Other Relevant Studies ... . . . . . . . . . . . . . 30

2.4 Evaluation of Existing Studies $\ldots \ldots \ldots \ldots \ldots$

Chapter 3: THE SEEKONK WATERFRONT STUDY, Page 37

3.1 Area \#3 - Boundaries of Study Area ............ 37

a. The Seekonk River Waterfront Study

b. Boundaries of Study Area Sub-sections

3.2 Inventory of Existing Conditions 38
a. Demographics
b. Environmental Constraints
c. Land Use Inventory
d. Circulation 

e. Economic Activity
f. Historic Preservation
g. Waterfront Access
h Infrastructure
i. Plans, Policies, Zoning

3.3 Trends and Issues . . . . . . . . . . . . . . 65

a. Neighborhood Trends and Issues

b. Availability of Waterfront Land for Development

c. Availability of Waterfront Recreational Facilities

d. Protecting the Residential Characters of Neighborhoods

e. Citywide Demands on Land Use

f. Land Use demands on the Lower River Section

g. Historic and Environmental Preservation

3.4 Recommendations for the Seekonk Waterfront $\ldots \ldots \ldots 71$
a. Land Use
b. Public Policy/Regulation
c. Improvements

3.5 Evaluation of Seekonk River Study . . . . . . . . . 80

\section{Chapter 4: RECOMMENDATIONS FOR THE PROVIDENCE WATERFRONT, Page 81}

\subsection{Strengthen Relationship between Waterfront Land Uses} and the Harbor . . . . . . . . . . . . . . . . 82

4.2 Strtengthen the Land Uses Appropriate to each Area of the Waterfront .................. 85

4.3 Mitigate the Negative Impacts of Development along the Waterfront . . . . . . . . . . . . . . . . . . . 89

4.4 Provide Integrated, Long Range Planning along the Waterfront .................. 93

4.5 Waterfront Implementation Table . . . . . . . . . . 97

\section{BIBLIOGRAPHY}




\section{LIST OF FIGURES}

Figure

3.1

3.2

3.3

3.4

3.5

3.6

3.7

3.8

4.1
Title

Income, Area Three

Ethnic Distribution, Area Three

Providence Noise Standards

Noise Levels, Area Three

Land Uses, Area Three

Peak Traffic Volumes, Area Three

Business Activity, Area Three

Historic Sites, Area Three

Land Use Change on the Waterfront 


\section{LIST OF MAPS}

$\underline{\text { Map }}$

2.1

2.2

2.3

2.4

2.5

2.6

3.1

3.2

3.3

3.4

$3.5 \mathrm{a}$

$3.5 \mathrm{~b}$

3.6

3.7

3.8

3.9

3.10

3.11

4.1
Title

Waterfront Guideplan Study Areas

Study Area One

Land Uses, Area One

Major Environmental Issues, Area One

Principal Economic Activities, Area One

Land Uses, Area Two

Study Area Three

Swan Point Section

River Avenue Section

Lower River Section

Water Resources, Area Three

Floodplains, Area Three

Land Uses, Area Three

Land Uses, Swanpoint Section

Land Uses, River Avenue Section

Land Uses, Lower River Section

Waterfront Access, Area Three

Recommended Land Use, Area Three

Recommended Land Use, Providence Waterfront 


\section{Chapter 1:}

\section{INTRODUCTION}




\subsection{Topic of Research}

Historically, the primary land use of the majority of the Providence waterfront has been industrial and commercial uses. The Port of Providence, located on the southern section of the waterfront, has served as a regional trade center for most of the City's history. The northern area of the waterfront, along the Seekonk River, has had a quite different land use history. Residential and commercial uses have been the primary historic land uses.

Although the diversity of uses along the Providence waterfront is still present, development pressures are bringing historic waterfront land use practice and policy into question. Issues such as economic development, housing and scarcity of land have brought controversy as to the best use of the waterfront as a City resource. Developers, preservationists, environmentalists, and fiscal planners all differ on needed policies and actions.

Although there have been studies completed on segments of the waterfront (such as the Port), no study has yet integrated these studies into a unified plan for the entire waterfront. To assure the best land use practice by the City along the Providence waterfront, a study is needed to look closely at waterfront resources. It is important that the City adopts a land use plan for the whole waterfront which applies consistent land-use planning methods to all areas of the waterfront. Overall Goals and objectives must be generated for the waterfront to provide a guide for future changes which will increase the overall value of the waterfront to the public. 
Further, the City has plans to create a Harbor Management Plan for the Management of its harbor resources. A Harbor Management Plan (HMP) is concerned with the interaction of water and land resources. To establish an effective HMP then, the City must have land use plans and policies which will interact with and reinforce harbor management.

\subsection{Purpose of the Waterfront Guideplan}

The purpose of this document is to consolidate existing waterfront plans in the City of Providence into a single plan: The Waterfront Guideplan. The resulting document considers existing land uses, land-use issues, goals and objectives for all parts of the Providence Waterfront and how they contribute to an overall City Waterfront plan. Although the construction of a single consanguous waterfront plan for the City is too large to accomplish at this time, this document attempts to provide contiguity between several waterfront studies in Providence including all areas of the Waterfront. Efficient planning for the diverse conditions and needs which exist along the waterfront is best accomplished through a single waterfront plan. Therefore, by placing each existing study within a single structure and establishing a loose association between the issues and goals of all waterfront areas, a platform is created for future waterfront planning and consideration of development impacts on the waterfront on the whole. Waterfront studies have already been prepared for most of the Providence Waterfront. However, the Seekonk River Waterfront 
still remains the sole area not to be singled out for land use study. This land use study is provided in this document as part of the Waterfront Guideplan. Together, the Seekonk River study and the existing land use studies make up "The Providence Waterfront Guideplan". This inclusive guide for land use planning on the Providence Waterfront should be considered a living document, and should be updated periodically to reflect the evolution of waterfront goals and to support revisions in the Comprehensive Plan of the City.

\subsection{Methodology}

The creation of the Waterfront Guideplan includes two tasks; the study of the Seekonk River Waterfront, and the consolidation of all waterfront studies into a single waterfront planning document. The latter requires the review and analysis of each document and the establishment of issues and recommendations for the entire waterfront.

Studying the Seekonk River also requires analysis to determine issues and to make recommendations. However, this task also requires the application of quantitative methods to generate data which will offer insight and suggest the most appropriate planning for the area. These methods include a series of descriptive techniques to create a snapshot of existing conditions. These methods include (1) review of neighborhood demographic information, (2) an inventory of existing land use, zoning, taxation, public access, development constraints (3) research and 
identification of environmental and economic considerations, and (4) review of transportation, recreation and infrastructure systems.

The identification of land use issues and corresponding recommendations are based first on the review of observations and descriptive information generated from statistical analysis, inventory creation, and overlay analysis. Interviews with key figures offered information and insight into the resolution of waterfront issues. Finally, analysis was synthesized into a textual review of major issues, corresponding goals, and rational planning recommendations.

\subsection{Scope of the Study}

The purpose of this document is to provide a planning tool which facilitates the interrelating of various waterfront studies into a single waterfront plan for the City of Providence. However, the scope and depth of the waterfront analysis presented in this study is, by necessity, limited. Because of the level of analysis, this document cannot include all issues important in waterfront planning. The primary purpose is to create a link between the various waterfront areas and their corresponding studies through a consolidation of major issues and goals. Therefore, use of this document should be for coordination and reference. Detailed planning for any part of the waterfront should be done in conjunction with specific studies and plans created for that area. 


\subsection{Organization of the Study}

The document is organized into three chapters. This chapter describes the organization of the guideplan and the definition of its boundaries. Chapter 2 provides existing planning information on the City's waterfront. It reviews the most recent land use studies and recommendations currently influencing the waterfront. Chapter 3 provides a land use analysis of the Seekonk River to complete the study of the entire Providence waterfront. Finally, Chapter 4 sets the stage for future land use and harbor planning by assimilating the waterfront issues, goals and recommendations into a single list of waterfront issues and goals. The resulting guideplan reflects citywide concerns and goals for its waterfront.

\subsection{Definitions.}

Access, Public: Generally, Public access to waterfront areas includes physical means for the public to access shoreline areas. This is accomplished through public ownership of waterfront land or the establishment of a Right-of-Way (ROW) to the shore.

Access, Direct: Waterfront areas which are owned by the public or where a public ROW exists, which provides individuals with direct contact with the water (swimming, boating, etc.). These areas may include beaches, boat ramps, or other uses where no obstacles exist.

Access, Indirect: Areas owned by the public or where a public ROW exists which does not provide individuals with direct contact with 
water. Direct access to the water is available but only by crossing one or more obstacles (road, wall, berm, etc).

Access, Visual: Areas where a visual corridor to the water exists. These areas may be privately or publicly owned and may provide extensive, little or no physical access.

Access, No: Areas where, although visual access may exist, no physical access to the shoreline is available to the public. These areas may be publicly or privately owned.

Combined Sewer Overflow (CSO): During periods of rain, water levels often exceed the capacity of city sewers. At that point, stormwater runnoff combined with raw sewerage overflows from city sewers and runnoff directly into the harbor without treatment.

Floodplain: Low lying land areas which are prone to flooding during various storm events. Flood insurance maps, maintained by the City, delineate floodplains within Providence. Construction within floodplains are generally required to withstand 50 to 100 year storm events.

Groundwater: Water reservoirs located beneath the ground surface. Groundwater quality is significant in its contribution to nearby surface water resources and to groundwater aquifers used to supply public drinking water.

Harbor Management Plan (HMP): An HMP is a document prepared by a city or town which sets forth goals, objectives and 
recommendations for water uses within its jurisdiction. An HMP is primarily interested in the interrelation of land and water uses.

Harbor: The tidal waters between Providence and East Providence. These waters include the Seekonk River south of the ProvidencePawtucket line, the Providence River north of the ProvidenceCranston line, and the tidal waters south of Crawford Street. The physical boundaries of the harbor can be identified using harbor maps of the City.

Infrastructure: Public services such as sewer and water which are supplied to residences and businesses within the City and maintained by public or quasi-public agencies.

Port: The facilities along the western edge of the Providence River from Field's Point at the Providence-Cranston north to the Hurricane Barrier and Narraganset Electric, and waters surrounding this area which are used for navigation of commercial vessels.

Waterfront: All land adjacent to and abutting the tidal waters along the Providence Harbor and extending in-land 500 feet or more depending upon the location and land use.

Water-Dependent Uses: Land uses which are dependent upon the water to function. They include such uses as commercial fishing companies, public/private docks or marinas, etc.

Water-Enhanced Uses: Land uses which do not depend upon the water to function, but are improved by their location adjacent to it. They include such uses as restaurants, residential uses, parks, etc. 
Non-Dependent Uses: Land uses which derive no benefit by being located adjacent to water. They include uses such as gas stations, grocery stores, professional offices, etc. 


\section{Chapter 2:}

\section{OVERVIEW OF PROVIDENCE WATERFRONT STUDIES}


Planning for the Providence waterfront has been carried out in several specialized land use studies focusing on specific areas of the waterfront. Cumulatively, study of the Waterfront has stretched from the Providence-Cranston line at Fields Point to Richmond Square along the Seekonk River. Two Studies will be considered as primary documents for land use planning along this area. These two studies cover areas one and two of the three planning areas considered in the Waterfront Guideplan. The entire waterfront and the three study areas are outlined on Map 2.1. The planning documents addressing areas one and two analyzed land use conditions at the time of the study, identified needs and goals, and made policy and development recommendations. To assimilate the two planning areas into the waterfront Guideplan, planning goals and recommendations have been summarized below. Emphasis has been placed on conditions, major issues, goals, and recommendations in each Waterfront study area. Detailed information on each area is left to individual study documents while overall land use considerations are presented to facilitate the consolidation of waterfront planning efforts.

\subsection{AREA \#1 - PORT OF PROVIDENCE}

a. The Waterfront Land Use Study

The Waterfront Land Use study was carried out by Vanasse Hangen Brustlin, Inc. and completed in 1990. This study provides an authoritative land use study on the Port and adjacent areas. Land 
PAWTUCKET

Waterfront Guideplan

MAP 2.1

Study Areas
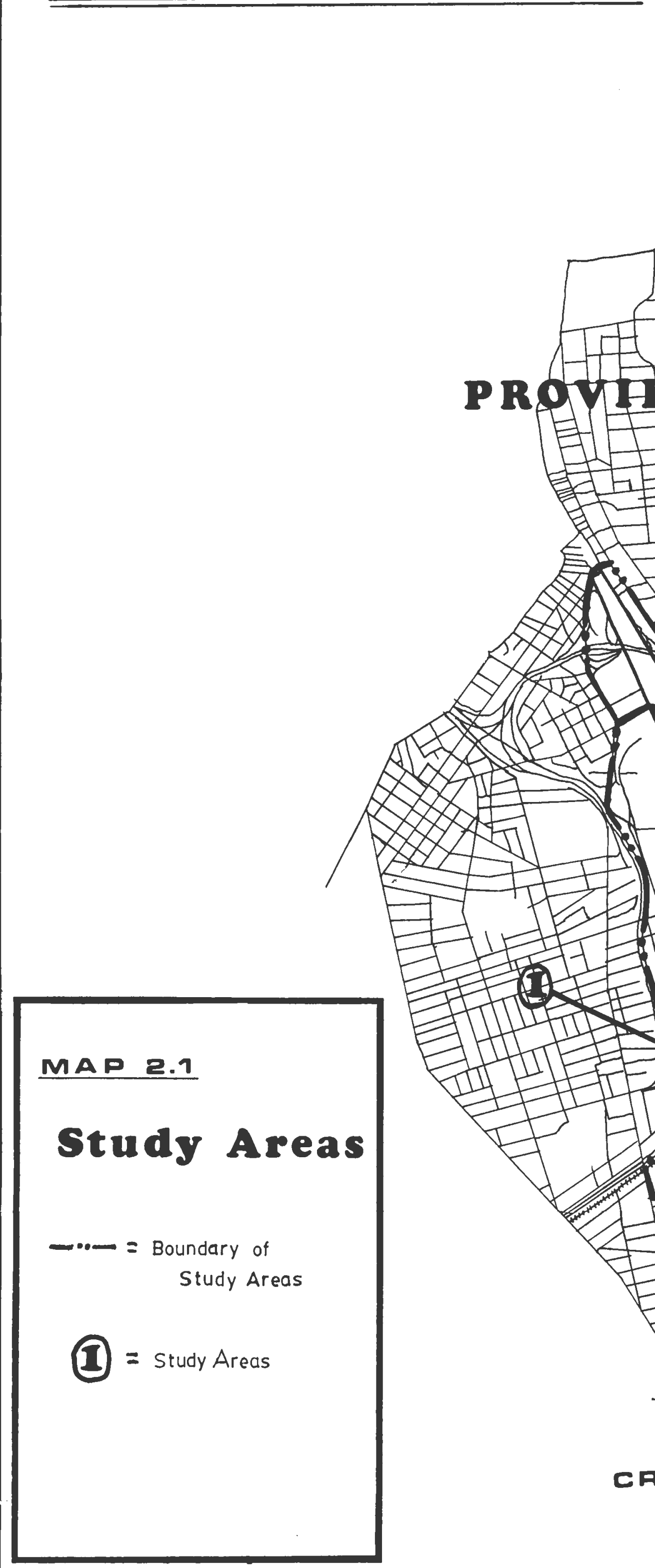

PRovHotce
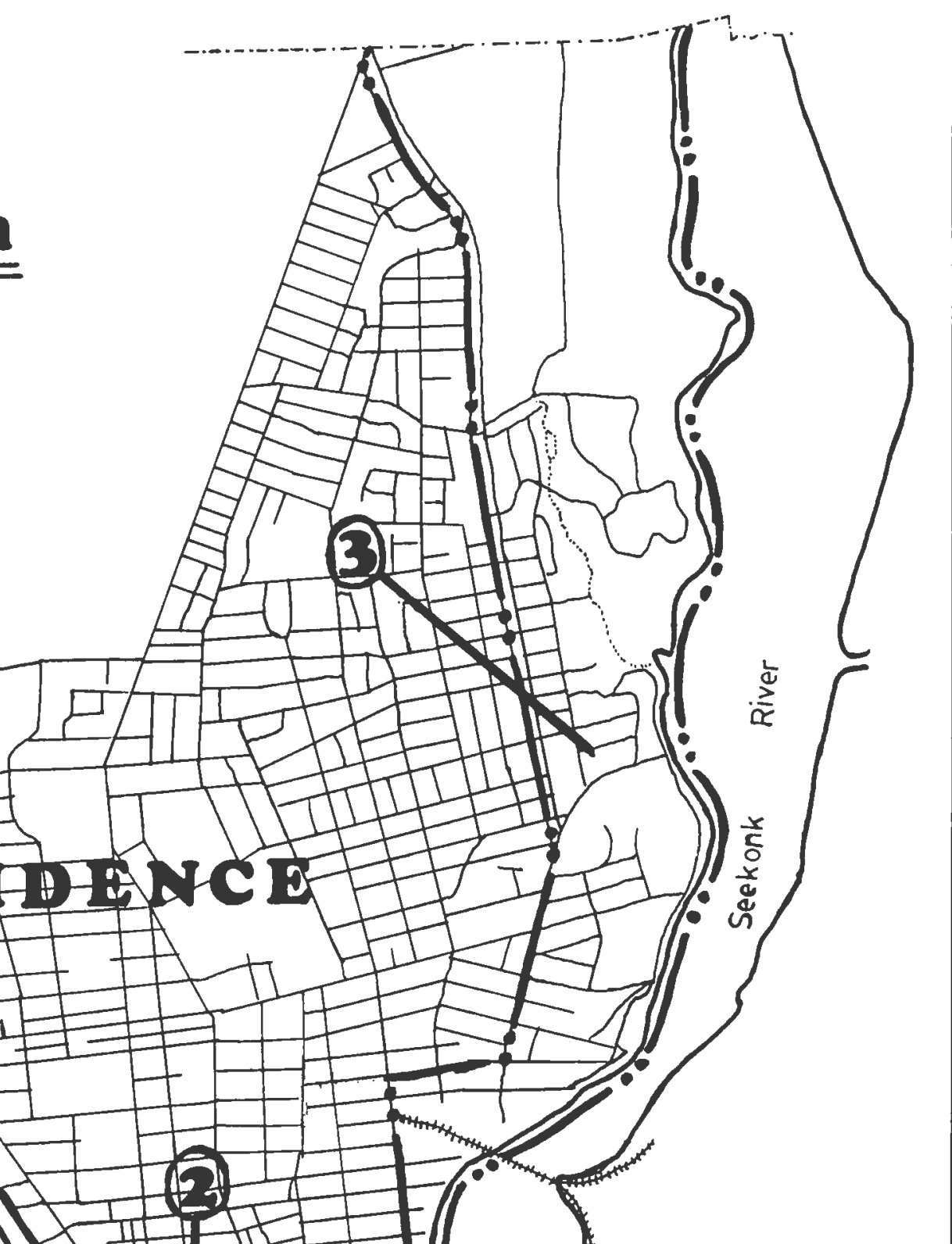

EAST

PROVIDENCE

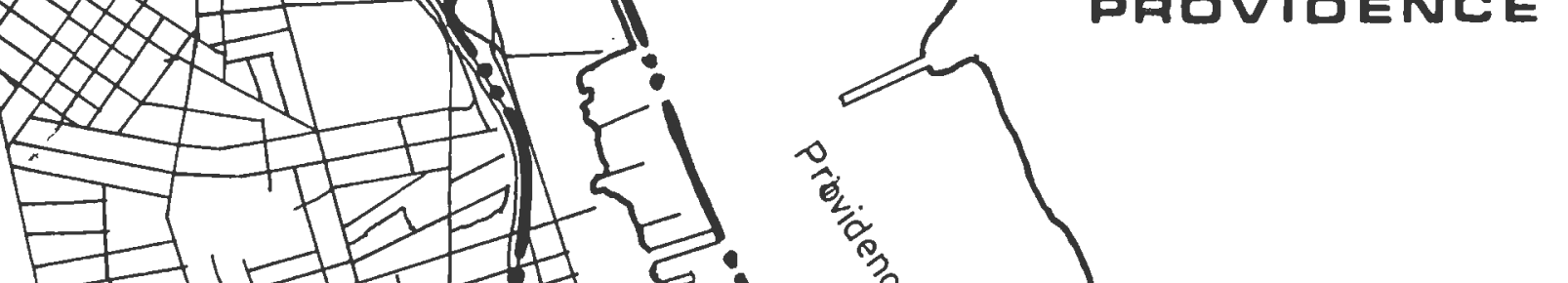

CAANSTON 
use recommendations were based on the consideration of existing natural and built environments as well as economic variables. Recommendations were offered for the management of City assets, physical improvements, and future land use policy. The study is summarized below.

b. Boundaries of the Study area

Study area \#1, considers waterfront land use along the west side of the Providence River and includes the land areas outlined on Map 2.2 The study focused primarily on the role that the Port plays within the City and how it interacts with and impacts surrounding land uses.

\section{c. Existing Conditions}

1. Land Use: Map 2.3 presents the land uses in Study Area \#1. The predominant land-use in this area of the waterfront is industrial. The study area is best characterized as marine-related industry, general industry, and warehousing with some office and very little commercial/retail uses.

At the southeastern tip of the study area, a 90-acre municipal wharf is utilized for bulk storage of such things as lumber, steel, scrap iron, and cars. This land is actively utilized with only one unused parcel present.

The Washington Park residential neighborhood lies in the southwest portion of the study area. This section is the only residential land 


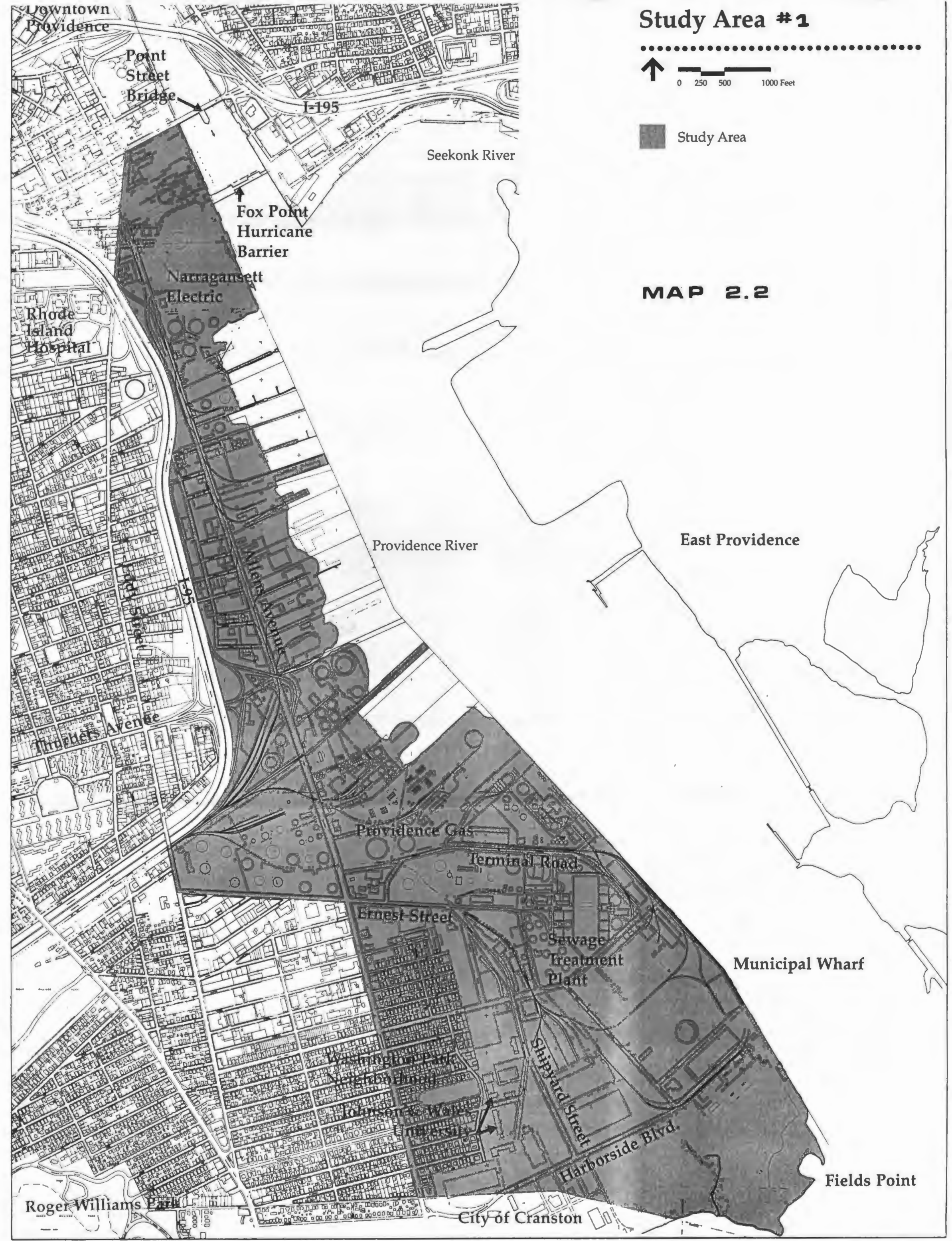




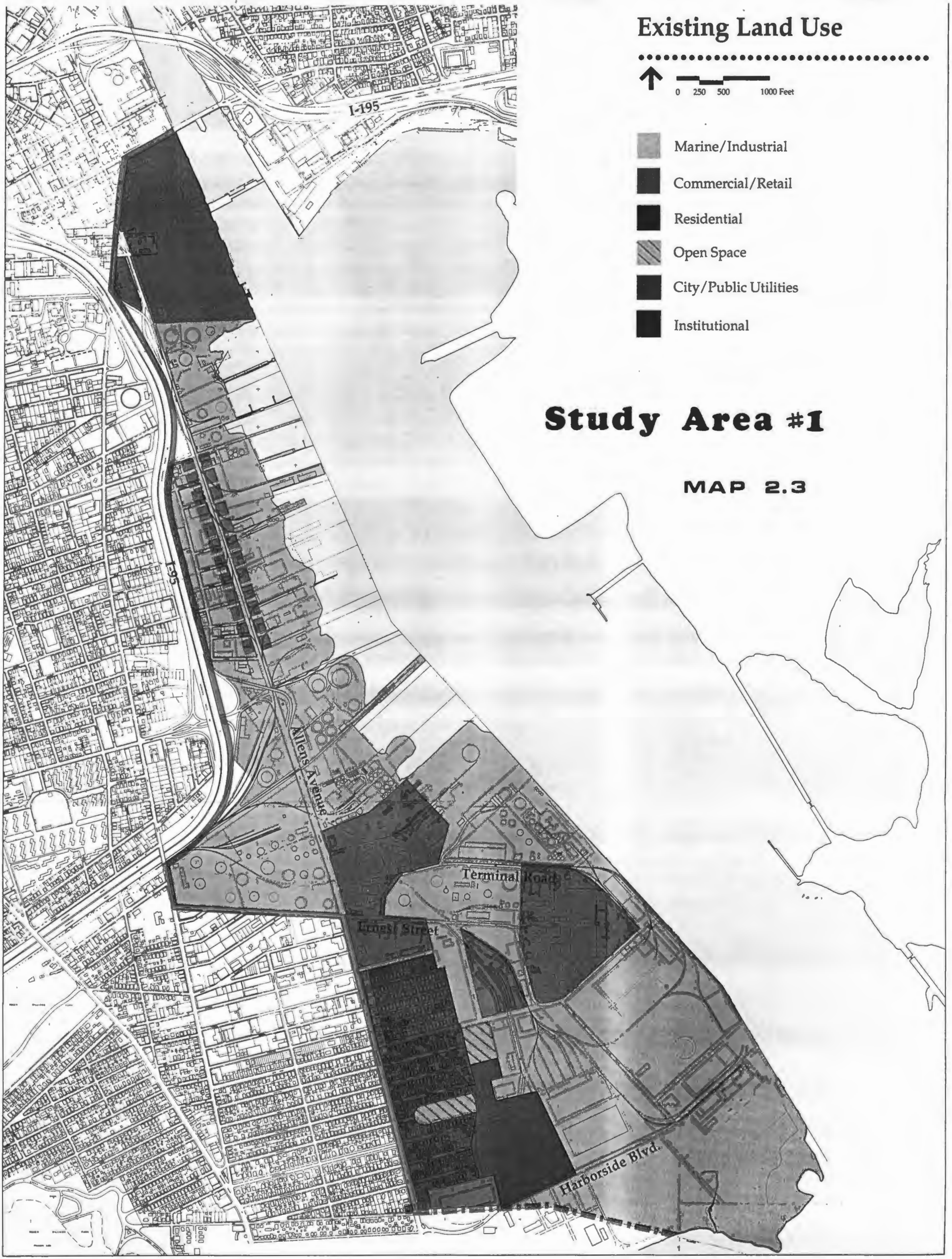


use in this study area. It also hosts the only recreational land uses in the study area; a park and a playground behind Johnson \& Whales University.

To the west of the municipal wharf are general industrial land uses and under utilized land. The Field Point Sewage Treatment Plant, the waste transfer station, the INGE parcel, and Johnson \& Whales University are all located in this area. Land uses by Johnson \& Whales University do not include campus uses. This land is utilized for offices, classrooms, a gymnasium, and some residences in five buildings.

In the northern section of the study area a number of petroliumrelated industries are present. The City Department of Public Works is located here as well as yards for the Department of Transportation. North of the Thurber Avenue exchange with I-95, the land uses begin to diversify. Although the primary land use continues to be general industrial, there are also restaurants present. Vacant lots are present along with areas used for storage and parking areas west of Allens Avenue. Industrial buildings with large lots (much of which are used for storage, parking or junk) are present on the west side of Allens Avenue and fronting directly on the water.

North of this area are petrolium-related and marine-related industry, including Narraganset Electric's Manchester Street Station. 
Just to the north of the study area is Davol Square, a commercial/retail complex.

2. Environmental: Existing Environmental conditions reflect the urban industrial setting. Only three vegetated areas of interest exist in the area: (1) Field's Point; (2) a drainage ditch opposite the east end of Thurber's Avenue; and (3) an area supporting salt marsh vegetation just south of State Pier No.1. The largest of these areas is Field's Point where weed species such as goldenrod, poor man's pepper, giant polygonum, and other species are found. Salt marsh vegetation was also identified including saltwater cordgrass, sea lavender, and marsh elder. The second largest vegetation area, the drainage ditch at the east end of Thurber's Avenue, are influenced by tidal activity. The banks are vegetated by a mixture of "weed" species and trees. The only other significant area of vegetation lies immediately north of the Shepard Warehouse and south of State pier No. 1. Here, several additional patches of saltwater cordgrass were found.

There are four mapped soils within the study area. These include: Matunuck mucky peat, Udortherts - Urban Land Complex, Urban Land, and Merrimac - Urban Land Complex. The majority of the study area is characterized by Udortherts-Urban Land Complex and Urban Land. The other soils can be found in two locations: The Matunuck mucky peat is restricted to the drainage ditch at the east end of Thurber's Avenue, and the Merrimac-Urban Land Complex is located in the Washington Park Residential section. 
Water quality in the Providence River is generally classified as SC waters. However, the quality of the water rapidly decays after a rainfall of one-half to one inch due to increased sewage and combined sewage overflows. These contaminants, along with overflow from the Treatment Plant, are considered the major sources of pollution to the water.

Potential industrially related hazards exist in this study area. These hazards include: (1) chemical storage; (2) liquefied natural gas; (3) liquefied propane gas; (4) concrete storage; (5) scrap metal storage; and (6) delapidated piers. The most significant of these hazards is the potential health risks from the rupture, leak, or explosion of any of the large number of petroleum and chemical storage tanks. Along with these existing hazards, previous contamination of waterfront soils may exist from past uses and may be a constraint in future redevelopment.

Because it is bordered by the harbor on the east and interstate 95 on the west, the negative impacts of the port facilities are confined to the Washington Park neighborhood, Johnson and Wales University, and the harbor itself. Map 2.4 summarizes the location of major environmental issues effecting the study area.

3. Transportation: Vehicular and rail access to the study area includes regional access from I-195, route 1A (Allens Avenue) and the Providence and Worcester Railroad (R\&W). There are three highway access points between the study area and I-95. These are 


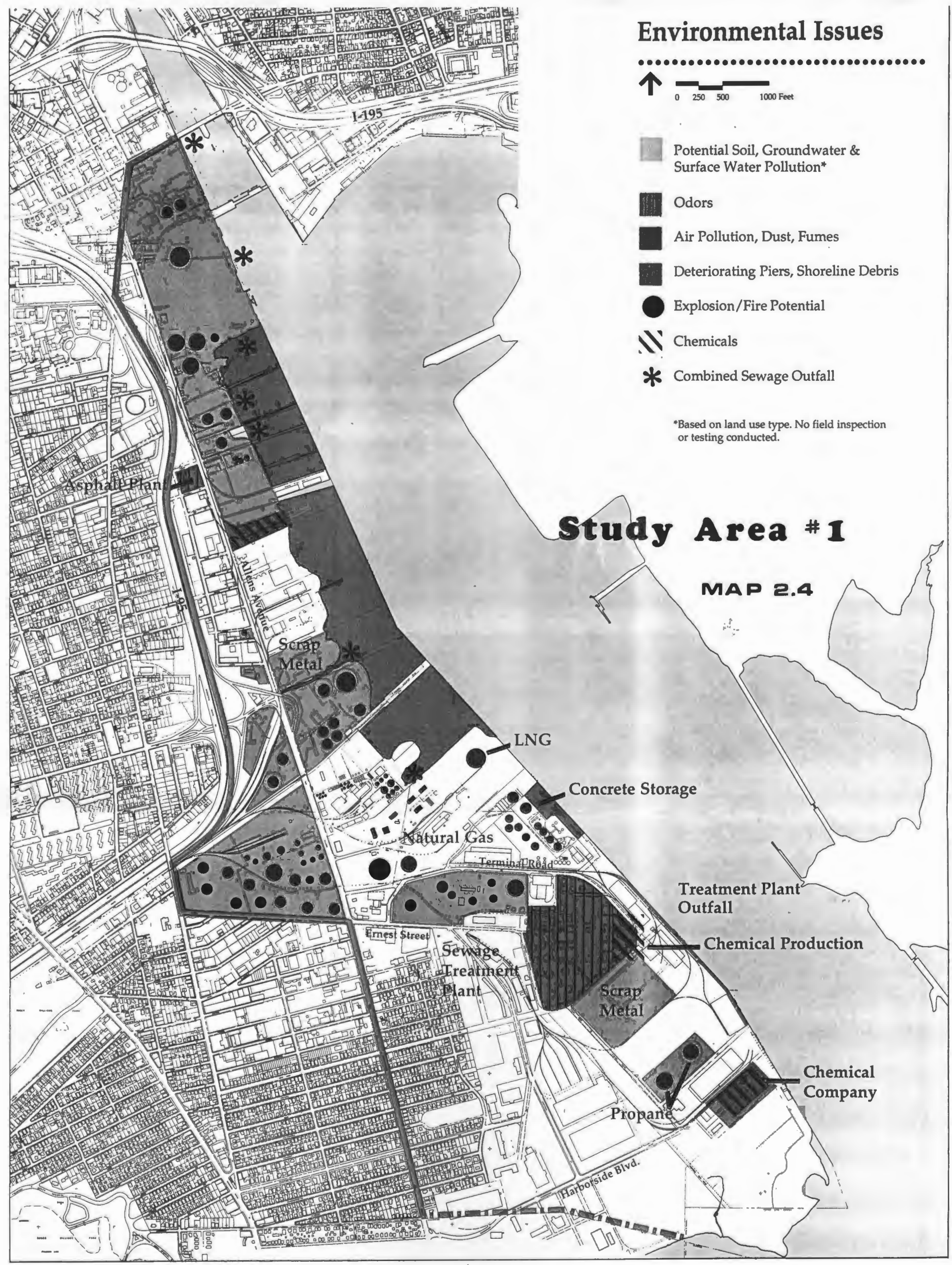


from Eddy Street Dyer Street near the Point Street Bridge; Eddy Street; and Thurbers Avenue. Rail tracks serving the Port are considered secondary tracks due to relatively low amounts of rail activity. However, volume on the three existing lines exceed 2000 railroad cars per year. Upgrades to roadway crossings within the study area are planned by the railroad.

Two bus routes, operated by the Rhode Island Public Transit Authority, serve the area. The No. 3, "Warwick Avenue", proceeds down Dyer and Allens Avenue turning onto Ernest Street away from the Port area. The No. 1, "Eddy Street", turns onto Narraganset Boulevard from New York Avenue and crosses the City line.

Movement within the study area is constrained by I-95 which creates a physical barrier between it and development on the west side of the highway. Roads which provide access between the two areas include: Blackstone Street, Public Street, O'Connell Street, Oxford street, and Thurbers Avenue. Traffic along Allens Avenue is a mixture of several trip types including: commuter through traffic, commercial activity along Allens Avenue, commercial activity to the Port of Providence, and residential traffic from nearby neighborhoods. Roadway improvements planned within the area along with implementation time frames where provided in study, but are no longer up to date.

4. Infrastructure: Water is served to the study area by major transmission mains supplying water from the north, west and south. 
Water Board personnel report that the water system, installed from 1892 through 1986, is generally free of tuberculation and corrosion. They state that the system appears adequate for existing needs.

Gas is received through cross country pipelines and stored within the study area on Terminal Road. The storage tanks located here serve Providence and East Providence and provides gas to Narraganset Electric for electrical generation purposes. The Providence Gas Company reports that gas service in the area is adequate.

Underground electric lines provide the study area with electric power from the Narraganset Electric Company. Overhead electric lines exist along Ernest Street and continue south to the Field's Point section.

Sewers in the study area terminate at the Field's Point Waste Treatment facility where much of the City and region's wastewater is treated and released into the Providence River. Approximately 64 million gallons of wastewater is received at Field's Point each day. Drainage pipes exist to handle urban runnoff and combined systems exist to handle overflow. During storms combined sewage overflow takes place in various areas throughout the study area and high levels of untreated contaminants enter the river without treatment. The City has no Capital Improvement Plans for the infrastructure in this area, however, the Narraganset Bay 
Commission (NBC) is conducting a study on the combined sewer overflows which will be completed in less than two years.

A $\$ 42$ million upgrade has been completed on the treatment facility itself, and the Narraganset Bay Commission plans another $\$ 30$ million to improve the efficiency of wastewater treatment in the Providence harbor area.

5. Economic Development: Economic activity in the area is mostly industrially based with little commercial establishments. Activities range from the distribution of raw materials and energy to the delivery of food service and hospitality services. Map 2.5 presents the principal economic activities within the port area.

6. Development Proposals: Narraganset Electric has plans to build a new gas-fired power plant on its vacant property south of the Manchester street Station. This is expected to be completed by 1995. It also has plans for beautification of the existing station.

Texaco, Inc has applied to dredge both sides of its pier to a depth of 38 feet which would allow them to use more of their existing storage space.

The Port of Providence is in the process of completing a $\$ 1$ million improvement program. Dredging, paving and fencing projects have already been completed and the installation of bollards, a fendering system, and lighting are planned for the future. 


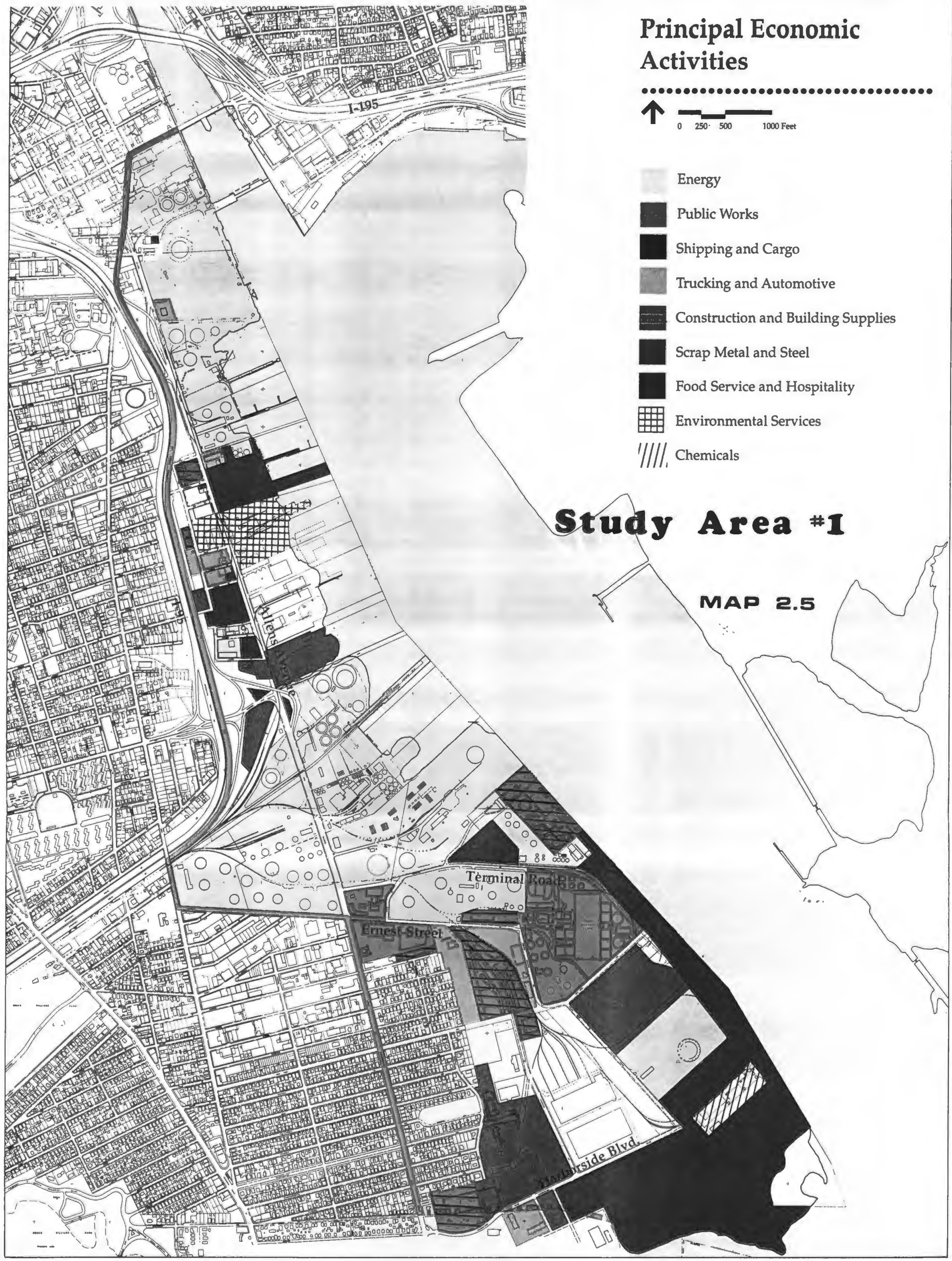


Possible expansion plans of the treatment facility may result from the Narraganset Bay Commission study of the combined sewer overflow and the Commission will be developing a sludge facility either on its own land or in the immediate area.

Newharbor, a mixed use development, proposes the establishment of 2,000 residential units, a marina, 330,000 square feet of retail space, office/commercial space, open space, parks, a hotel/conference center, and the retention of some of the existing water-dependent industrial uses.

\section{d. Issues, Goals and Recommendations}

The study suggests that the most important issue facing the waterfront is industrial preservation. The major recommendation made by this study is the preservation of water-dependent and water-related uses on the waterfront. A mix of water-dependent and non-dependent uses are encouraged including institutional use by Johnson \& Whales. However, primary attention should be paid to reserving land to be made available for port purposes.

Reparcelization of the lands located between Johnson \& Whales and the Port were recommended to create tracts of land for the development of marine-related industrial use. The development of a City program of assistance to maritime industrial businesses was recommended. The objective of this program would be to facilitate the development of the waterfront for water-related activities. 
Future residential uses within the study area were discouraged. However, the character of the existing residential neighborhood at Washington Park should be supported. Such actions as disallowing truck travel and other activities which threaten the health and welfare of the area as well as upgrading existing commercial areas were proposed.

A study is underway by the Narraganset Bay ports which could lead to the ability of the Providence Port Commission to raise its own funds to support capital improvement projects. This action would strengthen the Port's ability to contribute to its overall improvement and expansion. Major objectives recommended in the study include: (1) Better maintenance practice; (2) Public/Private partnership ventures; (3) Expansion into new market segments; (4) Improvement of signage to better create port identity; (5) Improve leasing arrangements in Port to reflect municipal objectives; and, (6) Adopt a future oriented approach and identify potential land which would be appropriate for expansion of Port facilities.

It was recommended that high priority be given to the improvement of infrastructure in the study area. This includes street and utility improvements, signage, and dock/wharf improvements. Other recommended physical improvements to the study area include: (1) Point Street Bridge improvements; (2) Allens Avenue Improvements; (3) Back street improvements; (4) Dredging and debris removal; (5) Improved port facilities; (6) Railroad 
relocation; (7) Increased public access; and (8) The establishment of methods to protect the environment in the area. These methods include the establishment of an emergency response plan to address spills, accidents or floods, and the evaluation of slope stability along the edge of Washington Park to protect against erosion or destabilization.

The study also recommended that the maritime uses of the port area be strengthened to assure the significance of the port to the region. Further, the establishment of a new light industrial development area was recommended.

\subsection{AREA \#2 - THE DOWNTOWN WATERFRONT}

\section{a. The Providence Waterfront Study}

The Providence Waterfront Study, was prepared for the Providence Foundation by William Warner. The study, completed in 1985 , considered three different study sections; the Old Harbor section, the India Point-Fox Point section, and the Lower Seekonk River section. As opposed to the "Waterfront Land Use Study" which focused on the function of the Port and its interrelatedness with other uses in the area, the "Providence Waterfront Study" focuses on the redevelopment of waterfront land to restore its aesthetic and economic value to the City. The document does not provide an indepth functional analysis of the existing conditions, especially the natural environment in these highly urbanized areas. Instead, the study takes a longitudinal analytic approach, examining the historic 
development of the waterfront area, changes in needs and policy, and the resulting conditions, assets and weaknesses of the current waterfront. The result is a concise planning framework for three waterfront planning areas reflecting efforts in architecture, urban design and planning.

Information provided in this study concerning existing conditions is not directly comparable with information provided in the previous study. Further, some of the goals and recommendations provided in this study may be outdated due to occurrences in the several years since the completion of the study. Therefore, future study to provide-up-to date and compatible information for this area of the waterfront is encouraged.

b. Boundaries of the Study Area

The boundaries of this waterfront study begin at Davol Square and the Narraganset Electric plant on the Providence River and continue up along the Seekonk River to Richmond Square. The study area also includes the Old Harbor area from the hurricane barrier up to the Crawford Street Bridge. Inland boundaries of the study areas include Pitman and Gano Streets in the Seekonk River study area, Route 195 in the Fox Point-India Point study area, and Dyer and Water Streets in the Old Harbor area. 


\section{c. Existing Conditions}

1. Land Use: Map 2.6 presents land uses in Study area \#2. Overall, there are 190 acres of waterfront land in the three study sections and 4.5 miles of waterfront, which accounts for $54 \%$ of the Providence Waterfront. The area is comprised largely of State roads and right-of ways (36\%). Residential and commercial uses make up $30 \%$ of all land uses, parkland accounts for $11 \%$, City streets comprise $10 \%$ and industry uses only $6 \%$. There are no publicly owned marine uses in the three study sections.

c. Issues, Goals, and Recommendations:

The primary objective set forth by the Providence Waterfront Study is the integration of waterfront redevelopment into city life and local patterns. Major goals presented by the Study for the Providence Waterfront include: (1) Re-establishing Providence as a waterfront City, (2) Reclaim the waterfront for recreational use and development, (3) Capitalize on the urban design resources and historic sites and structures along the waterfront, (4) Refocus planning and development toward the waterfront by locating appropriate water-related land uses, (5) Remove barriers to the waterfront, (6) Provide continuous public access along the entire waterfront, (7) Reconnect the waterfront to downtown and residential districts, (8) Reconnect water activities to waterfront land uses, (9) Develop transportation and parking alternatives, (10) 


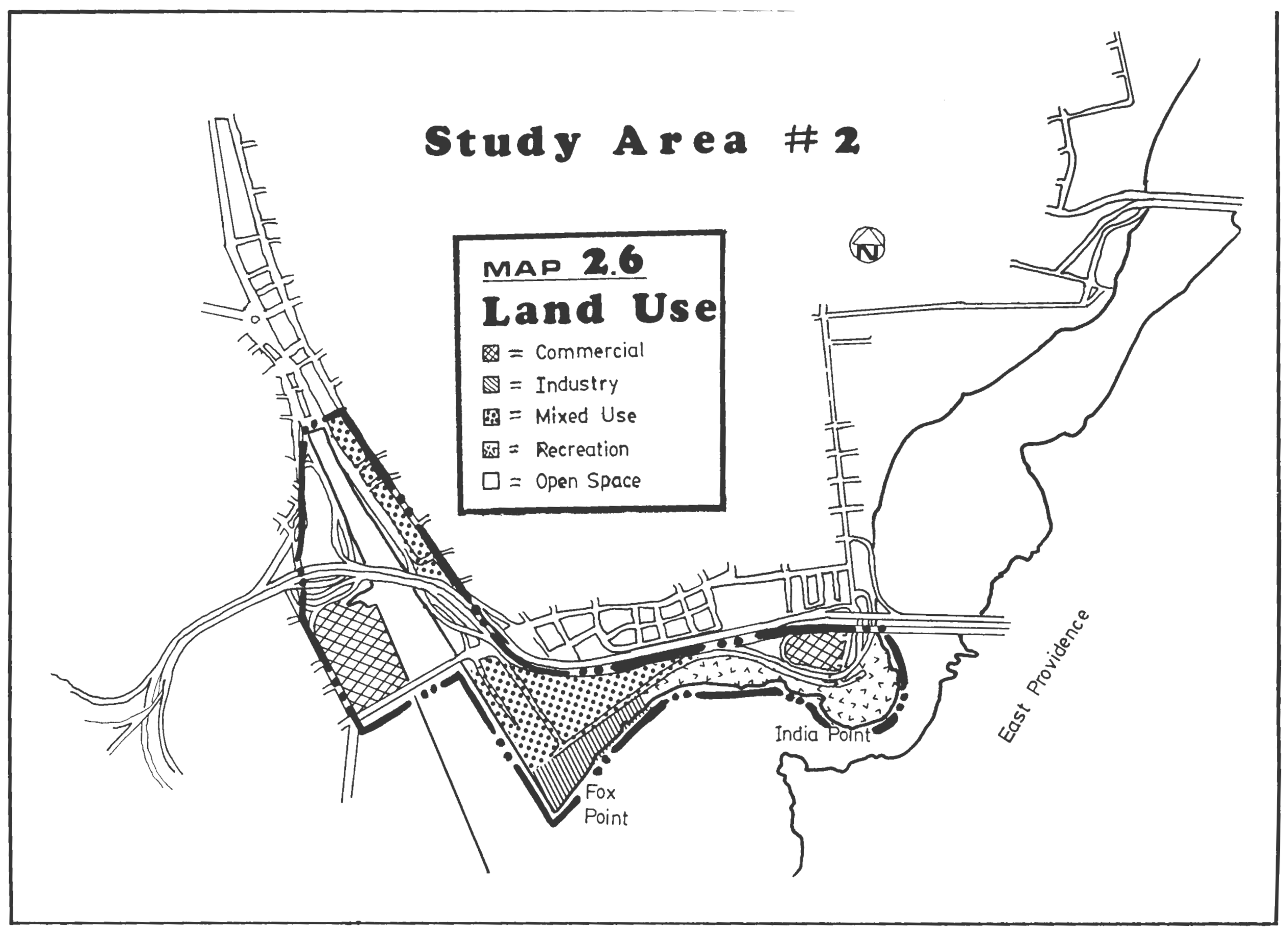


Reduce flood hazards, and (11) Create a linkage between isolated developments being planned along the waterfront.

The Study identified several objectives. Urban design objectives included the spatial integration of adjacent urban plans with the waterfront, the integration of existing parks with each other and the waterfront, and physical improvements supporting year-round use.

River improvement objectives included the development of marinas at India Point, Fox Point and South Water Street. Other river improvement objectives included the improvement of water quality, removal of debris, and the raising of overpasses to encourage boating.

Park improvement objectives included increasing access along the waterfront in the form of biking and jogging trails, increase activity in India Park by adding water and land structures for group events, and the increase of park areas and development of a special waterfront security force.

Private sector development objectives included the establishment of public access along the waterfront through development standards, opening up Fox Point for private development, building a residential high-rise overlooking the water, enhancing the historic ethnic character of the Fox Point neighborhood, consolidate and reduce industrial uses, use the abandoned bridges on the Seekonk River for museums or restaurants, and modify the unattractive aspects of the Narraganset Electric power stations. 
Circulation and parking objectives included the development of solutions to the Gano Street traffic problem, development of wellspaced parking garages, the development of a miniature trolley around the downtown and waterfront areas, the use of shuttle boats and ferries, and the use of the East Side Tunnel for a commuter shuttle train from East Providence to Downtown.

Specific recommendations for the redevelopment of each section of the Downtown Waterfront area where presented in the study. As stated earlier, this document considers only major land use issues, goals, and recommendations. However, because a detailed functional analysis of existing conditions was not used as the basis for land use goals and recommendations, a review of some of the detailed recommendations for each section of this study area (some of which are currently underway) is presented below to better clarify goals and objectives.

\section{THE OLD HARBOR SECTION}

\section{a. Boundaries}

The Old Harbor extends up the Providence River from the Hurricane Barrier north to the Crawford Street Bridge. These two points mark the north and south boundaries of the Old Harbor Waterfront Plan (Study Area \#2 in the Waterfront Guideplan) for this area. Land use recommendations include both banks of the old harbor from Davol square north to Crawford Street on the west bank, and from the 
Corliss Landing north to Crawford Street on the east bank. Inland boundaries are defined by Dyer Street to the west and Water Street to the east.

\section{b. Existing Conditions}

1. Land Use: This study area consists of 53 acres of land. $43 \%$ of the land (23 acres) is publicly owned. State roads include $41 \%$ of the the land and City streets comprise $2 \%$. Privately owned waterfront land covers $32 \%$ of the area. No vacant land, either public or private, exists in this area. The remaining $25 \%$ of waterfront land in the area is owned by public utilities.

The cost of land in this area is most significant in development. Land value in the Old Harbor Waterfront Area accounts for $48 \%$ of the total cost of development, as compared to land in the Fox PointIndia Point and Seekonk River study areas where land accounts for between 3 and 4 percent of the total cost of development.

The study area falls in the downtown district of the City. Two ramps off of Route 195 lead into the west and east side of the area providing direct access into the downtown area. The area functions as a major circulation area for traffic.

c. Issues, Goals and Recommendations

Public Improvement recommendations include: the elimination of the eastbound on-ramp to I-195 from South Water Street in order to open up over an acre of waterfront for public and private use; 
the consolidation of South Water Street and Service Road into one roadway in order to free up three quarters of an acre of waterfront for construction; and the realignment of downtown off-ramps from I-195 to Dyer Street in order to open up five acres and 1,200 linear feet of waterfront for development.

Recommendations to improve access and circulation included: make South Water Street into a two-lane road as the downtown extension of River Drive; make South Main Street between Waterman Street and James Street into a two-lane road; and at Davol Square, make Eddy and Richmond Streets a one-way loop to ease congestion at the intersection of Eddy and Point Streets.

Economic development recommendations included: create a 1 acre mixed use development on South Water Street above the Point Street Bridge; create a similar development site above the I-195 bridge on South Water Street; create a 5 acre high-density mixed use development area between Dyer Street and the Providence River; and Free up vacant lots west of Dyer Street waterfront for development by providing two large parking garages on Clifford and Dyer Streets.

To open up the rivers, recommendations included: installing a sill and boat lock in the hurricane barrier in order to maintain a constant water level in lieu of tidal lows and highs and to restore river traffic in the Old Harbor; and restore or replace the Point Street Bridge in order to permit up river traffic. 


\section{THE INDIA POINTIFOX POINT SECTION}

\section{a. Boundaries}

The Fox Point-India Point Section, is largest of the three study sections. The section includes the waterfront land between and including the Fox Point Triangle and India Point Park. The inland boundary of the area is defined by Interstate Route 195 .

\section{b. Existing Conditions}

1. Land Use: There are 71 acres of land in this study area. The dominant land use in the area is the Interstate highway. Of the total 71 acres, $77 \%$ of the land is publicly owned. The Interstate highway accounts for $44 \%$ of the land in the area, City streets make up $9 \%$, parks use $18 \%$, and $4 \%$ of the land is vacant. The remaining $23 \%$ of the land in the study area is privately owned, $20 \%$ occupied and $3 \%$ vacant.

Land values in this area account for only $3 \%$ of the total value of developed land in the area. This study area constitutes the only waterfront area in the three study sections with some degree of activity. Fox point is home to a tugboat company, boat yard and two restaurants at the water's edge, in addition to offices, warehouses and repair, storage and salvage yards. The Interstate has ramps at the Washington Bridge which are the only direct means of access to the area from outside the area. 


\section{c. Issues, Goals and Recommendations}

Public improvement recommendations in the area include: the replacement of the raised I-195 ramps at the Washington Bridge with more appropriately scaled ramps, freeing up land under the bridge for use and access to the Seekonk Waterfront; at Fox Point, replace the hurricane flood dike with a masonary floodwall capable of supporting building construction; and locate the new flood wall parallel with India Street with northern extensions at South Water Street connecting with the hurricane barrier and at Traverse Street, thereby creating 3 blocks of flood-protected land.

Recommendations to improve access and circulation included: raise India Street at the center of the park and extend Hope and East Streets from the residential neighborhoods across I-195 via a blockwide platform bridging the Interstate; and extend South Water Street through the hurricane floodwall to Point and India Street, thereby connecting the Seekonk River Drive with downtown on a three and one-half mile, continuous waterfront circuit.

Economic development recommendations included: creating a 2 acre site for residential and commercial rehabilitation of the old Standish-Johnson buildings on Gano and Tockwotten Streets by removing the raised ramps to I-195 which blocks access to the water; create a mixed-use waterfront development district on Fox Point; free five and one-half acres for development by redesigning and relocating the hurricane flood wall; promote new facilities for 
existing marine activities on the Point in order to maintain the character of the working waterfront.

Last, to open up the rivers, it was recommended: develop a public wharf at the new marine terminal for ferries, cruiseships and water taxis; cut out a 210 slip marina from the flood-prone land between India Street and Fox Point.

\section{THE SEEKONK_RIVER_SECTION}

\section{a. Boundaries}

The Seekonk River study section includes all of the waterfront area of the Seekonk River between the Washington Bridge and Richmond Square. The inland boundaries of the study area include Pitman Street and Gano Street.

b. Existing Conditions

1. Land Use: This section consists of 66 acres of land along the lower section of the Seekonk River. Publicly owned land includes $44 \%$ of this section. Of this public land, $20 \%$ is used for State right-of-ways, $4 \%$ for City streets, $15 \%$ for parks, and $5 \%$ is vacant. The remainder of this land is privately owned, $41 \%$ occupied and $15 \%$ vacant.

Land value in the area accounts for only $4 \%$ of the value of developed land. Much of the 29 acres of vacant land in the section is reserved for future development of streets and highways. 
c. Issues, Goals and Recommendations

Public improvement recommendations included the relocating of the Waterman Street ramp to the New Red Bridge in order to establish a better transition between the highway and local streets.

Recommendations for the improvement of access and circulation included: create a River Drive from Richmond Square along the Seekonk River and extending to India Street in India Point Park; extend Butler Avenue and East Transit Street to the proposed River Drive; and enhance the pedestrian entrances to the Gano Street playgrounds and the Seekonk River waterfront.

Economic development recommendations included: create a waterfront center of approximately ten acres at Richmond Square; create an eighteen acre site for residential or office use by extending Butler Avenue to the proposed River Drive; designate the existing site of the Salvation Army on Pitman Street as low-to-moderate income housing in the event the site is sold; and create a one-acre neighborhood housing site and provide for a community center on the Gano Street.

Finally, to open up the rivers, it was recommended that small boat docks and ramps and water taxi landings be developed along the proposed River Drive. 


\subsection{OTHER STUDIES RELATED TO THE WATERERONT}

a. Providence Comprehensive Plan 2000: Prepared by Providence Department of Planning and Development, 1990.

The Providence Comprehensive Plan 2000 establishes a number of goals, objectives and policies for the City which directly and indirectly affect Waterfront planning. Policies which effect waterfront planning can be found throughout the Comprehensive Plan. However, the areas of the plan which are most significant to the waterfront include: Land Use, Port Development, Environmental Protection, Historic Preservation, Open Space and Recreation. The waterfront relevant policies of the Comprehensive Plan are reviewed below.

\section{Land Use Policies}

- Encourage new light industrial and commercial business to locate in Providence.

- Monitor the expansion of institutions in the City and enforce the Institutional Overlay zone in order to protect residential neighborhoods from infringement.

- Study and provide open space and recreation areas in every neighborhood.

- Create buffer zones for residential uses from adjacent, noncompatible uses.

- Return non-productive land to the tax rolls. 
- Maintain compatibility with land uses in surrounding cities and towns, especially along border areas.

- Provide adequate, and appropriately located land for industrial and commercial revitalization.

- Encourage historic preservation and adaptive re-use where appropriate.

- Exercising design controls and reviews in appropriate areas and for appropriate developments.

- Exercising environmental reviews for projects above critical sizes.

- Preserving and enhancing environmentally important features such as views, river and harborfront areas.

- Provide public access to environmentally important features.

2. Port Development

- Reenforce the study area's industrial land use pattern.

- Strengthen the study area's functional relationship to the water.

- Minimize the effects of industry on nearby non-industrial land uses.

- Create a new light industrial development area.

These four basic goals are expanded into 68 policies and objectives in the Comprehensive Plan. Many of these have been adapted from the Study reviewed earlier. For specific policies, one may refer to the study of the area or the Comprehensive Plan. 


\section{Environmental Protection}

- Protect environmentally significant areas from development.

- Enhance and protect water quality in the harbor and other water resources.

- Protect future residents from potential development and environmental hazards.

- Improve air and noise pollution in the City.

- Decreasing the existence and creation of unnecessary man-made hazards, including structures, and point and non-point pollution sources.

- Protecting shore areas, waterways and waterbodies from harmful effects of development.

- Protecting water quality from the impacts of shipping and commercial activity.

- Promote shoreline recreational access and usage.

\section{Historic Preservation}

- Preserve areas and structures with historic significance.

- Discouraging the demolition of significant structures.

- Preservation of Providence's historic neighborhoods and improve livability.

- Encourage the implementation of innovative preservation techniques such as adaptive re-use and tax incentives. 


\section{Open Space and Recreation}

- Provide a variety of active and passive recreational facilities.

- Encourage public access to the City's waterfront.

- Protect important vistas throughout the City from future development.

- Study and redesign the various recreational areas in the neighborhoods and consolidate them to form larger, more regional recreational areas.

- Protect and monitor the natural amenities along the waterfront by pursuing the coordination of land use planning with neighboring communities.

- Remaining unique and significant natural areas in the City, including wetlands, woodlands and watersheds, should be protected from future development.

Major recommendations or conclusions by other studies concerning the waterfront are reviewed below (and drawn from "Waterfront land Use Study", Vanasse Hangen Brustlin, Inc.):

b. Port of Providence 2000 Study (1980): Prepared by Engenium, Inc.

- Extend Port jurisdiction to the limits of the current study area, excluding residential area.

- Extend land area to south and add a seventh berth to the Port.

- Develop container capacity.

- Extend exterior storage area, increase general cargo warehousing. 
- Provide new port facilities.

- Close Allens Avenue to public use, extend Fields Point Drive northward and reorganize and depress rail lines.

- Develop a system of port security, including a port police force.

c. Port Project Official Redevelopment Plan (1984): prepared by the Providence Redevelopment Agency.

- Revitalize port facilities.

- Dredge berths 3 and 4 to 35 feet.

- Add new bollards near berths 3, 4, 5, and 6 .

- Project area recommended to remain industrial.

d. CRMC Special Area Management Plan (1983): prepared by the University of R. I. Coastal Resources Center.

- Work with municipalities to develop waterfront plans and Statewide port program.

- Identify and monitor areas of concern, including the pier area north of the port and south of the State Pier.

- Establish water discharge limitations.

- Adopt water and shore use designations.

- Remove shoreline debris.

- Establish boat ramps.

- Designate and enforce new harbor lines in various locations.

- Designate sites for port expansion and dredge material disposal. 
e. Narraganset Bay Ports Study (1988): prepared by Martin O'Connell.

This study included economic, marketing and engineering studies. Conclusions of the economic study included:

- The Port of Providence created 1,428 direct jobs and 618 induced jobs, for a total of 2,046 jobs in 1987 .

- In 1987 , the port produced $\$ 41.7$ million in direct personal income and $\$ 31.7$ million in induced personal income, for a total of $\$ 73.4$ million in personal income.

- Taxes paid to the State and local government in 1987 amounted to $\$ 7.3$ million.

- Revenue for the commodities shipping by the port in 1987 was $\$ 159.6$ million.

\subsection{EVALUATION OF EXISTING STUDIES}

Future strengthening of existing information should be pursued in each waterfront study area to develop a consistent, in-depth, database on which to base waterfront land use decisions. Numerous gaps in waterfront data exist, as well as outdated or absent information which will need to be provided in future planning efforts.

Of the two studies reviewed, the Waterfront Land Use Study offers more long term land-use planning information. This document has been recently completed and provides a solid base for coordinated waterfront planning over the next several years. The goals and 
Chapter 3:

\section{THE SEEKONK WATERFRONT}




\subsection{AREA \#3 - BOUNDARIES OF THE STUDY AREA}

\section{a. The Seekonk River Waterfront Study}

The Seekonk River Waterfront Study area focuses on the portion of Providence waterfront shown in Map 3.1. The study covers the area along the Seekonk River from the Providence-Pawtucket line south to Route 195, and from the Seekonk River west to Blackstone Boulevard, Butler Avenue, Pitman Street, and Gano Street respectively. The study area was broken down further into three study sections based on character and individual planning issues. These three sections are: the Swan Point/Butler Hospital section; the River Avenue section; and the Lower River section. The Lower River section considered in this study overlaps with the study done in "The Providence Waterfront Study" by William Warner. The purpose of this is to provide a single waterfront study including the entire Seekonk River waterfront using similar methods of analysis.

b. Boundaries of Study Area Sub-sections

The Swan Point/Butler Hospital section of the study area, shown in Map 3.2, is made up of a portion of the Blackstone neighborhood. The boundaries of this area are defined by the ProvidencePawtucket City line to the north, Blackstone Boulevard to the west, beginning at Hope Street and continuing south to Laurel Avenue. Laurel Avenue from Blackstone Boulevard to the Seekonk River defines the Southern boundary, and the Seekonk River itself defines the Easterly border of the study area. 


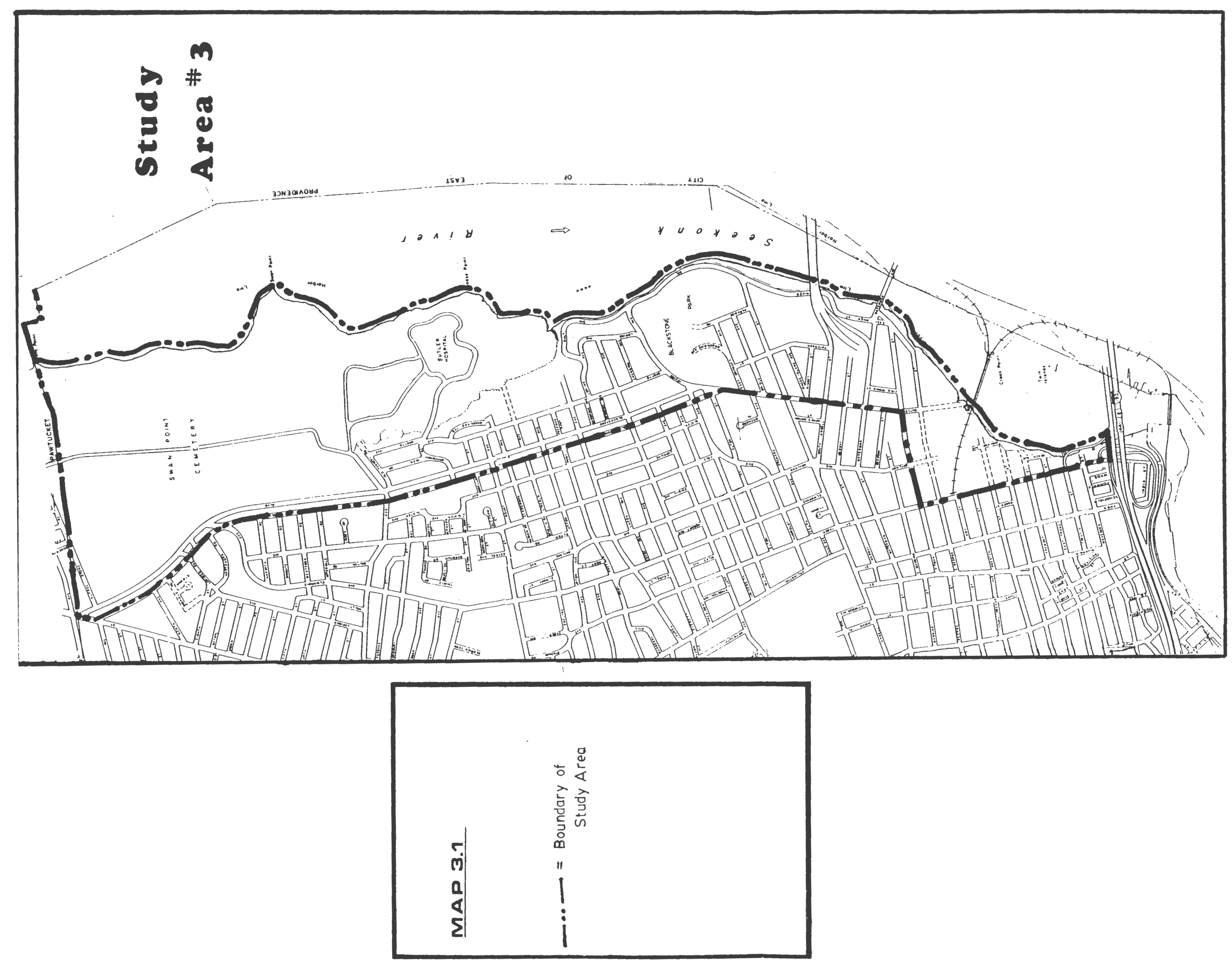




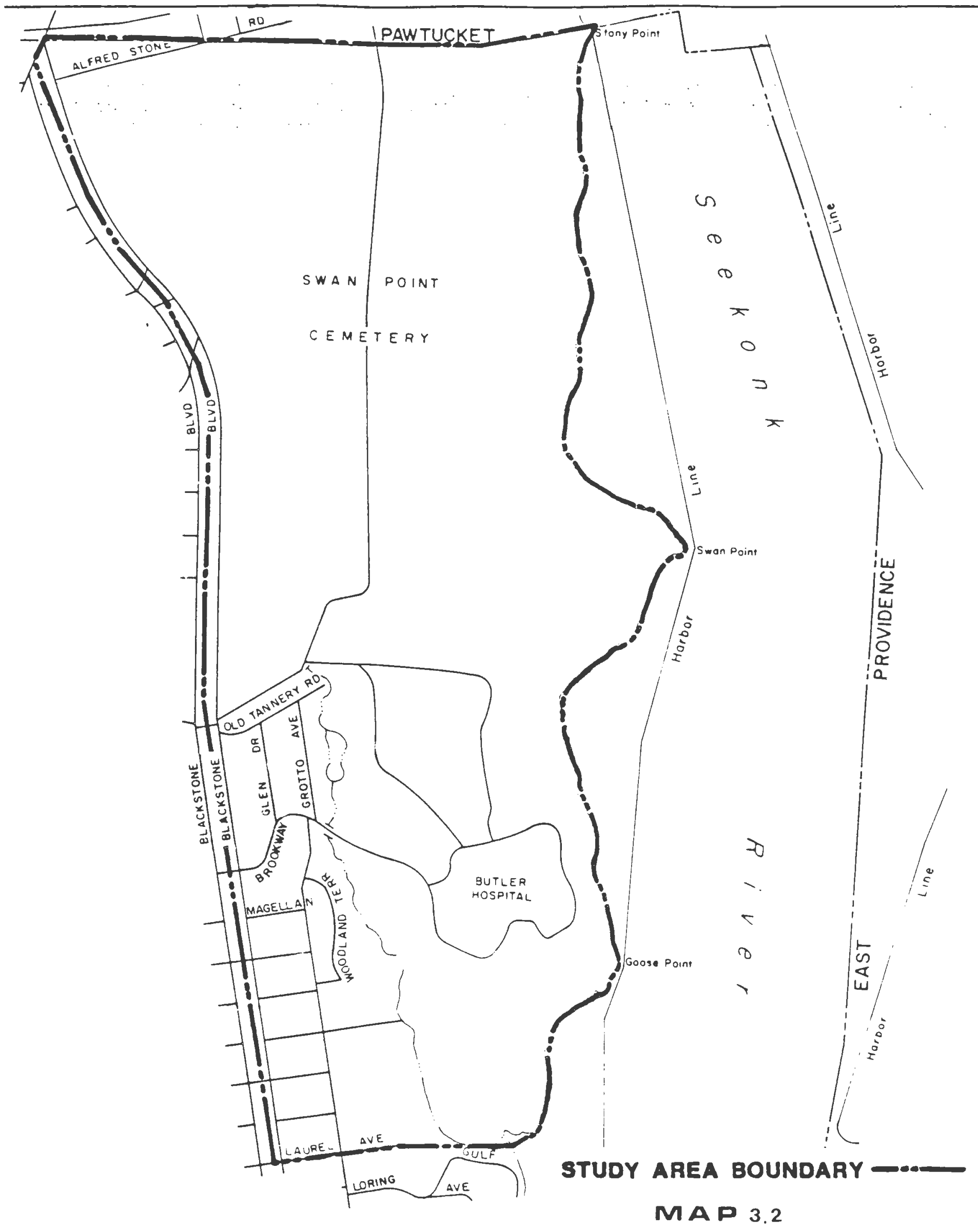

SWAN POINT / BUTLER HOSPITAL SECTION 
The River Avenue section of the study area, shown in Map 3.3, is made up partly of the Wayland neighborhood and a small portion of the Blackstone neighborhood. The northern boundary of the area is defined by Laurel Avenue. Blackstone boulevard and Butler Avenue define the west boundary of the area, and South Angell Street from Butler to the Seekonk River defines the south boundary of the area. The east boundary follows the edge of the Seekonk River.

The Lower River section of the study area, shown in Map 3.4, is made up of a portion of the Fox Point neighborhood. The northern boundary of the area is defined by South Angell Street from Butler Avenue to the Seekonk River. The west edge of the section is defined by Butler Street, Pitman Street, and Gano Street (from north to south). The Southern edge of the section is defined by Route I195 from Gano Street to the Seekonk River, and the east edge of the study section again follows the Seekonk River.

\subsection{INVENTORY OF EXISTING CONDITIONS}

\section{a. Demodraphics}

Consideration of some key demographic information is important in any planning study because it provides insight into the socioeconomic underpinnings of the area being considered. Demographic information regarding population, income, age, and ethnic composition was considered for the three study sections to 


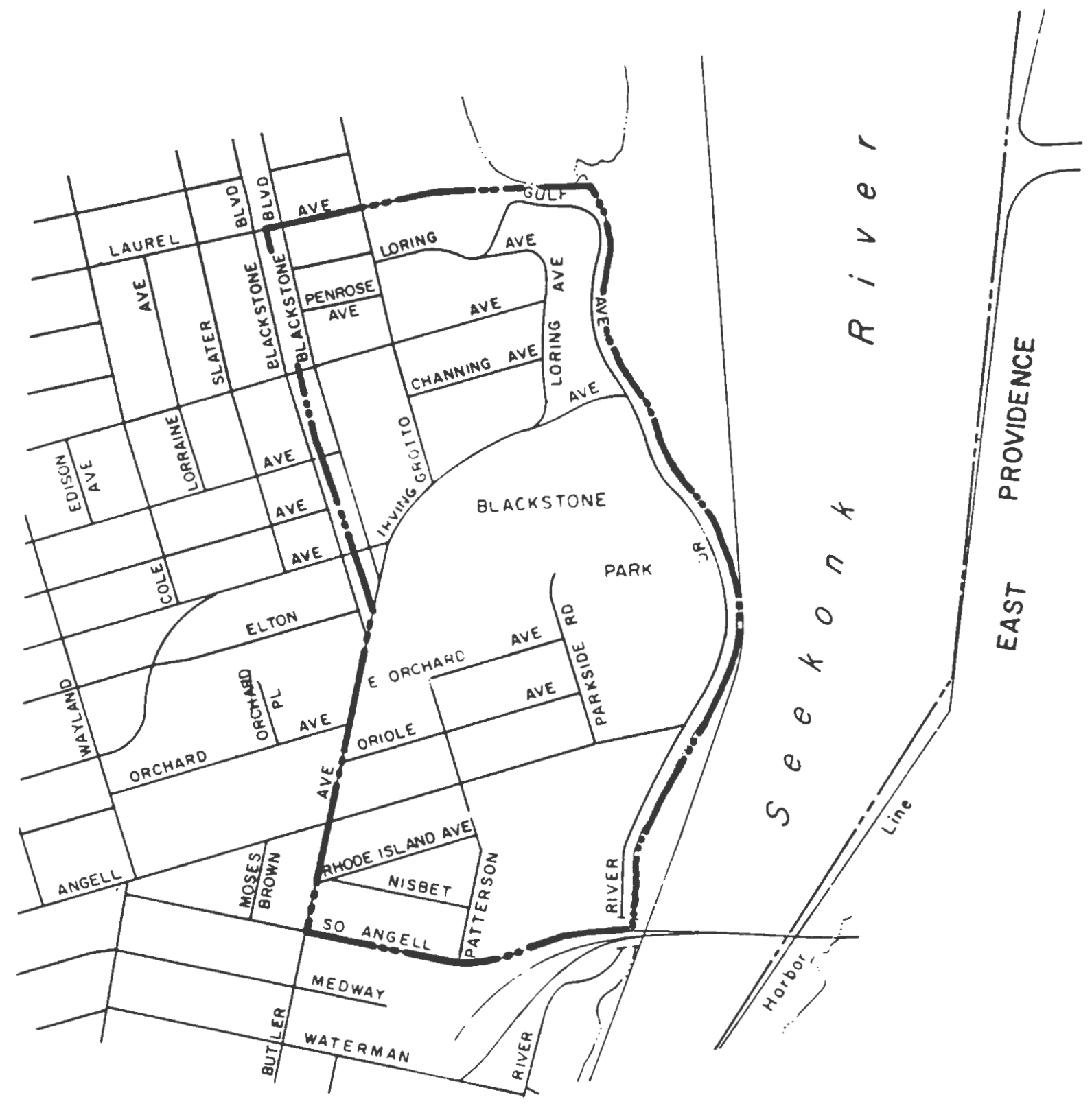

STUDY AREA BOUNDARY

MAP 3.3 


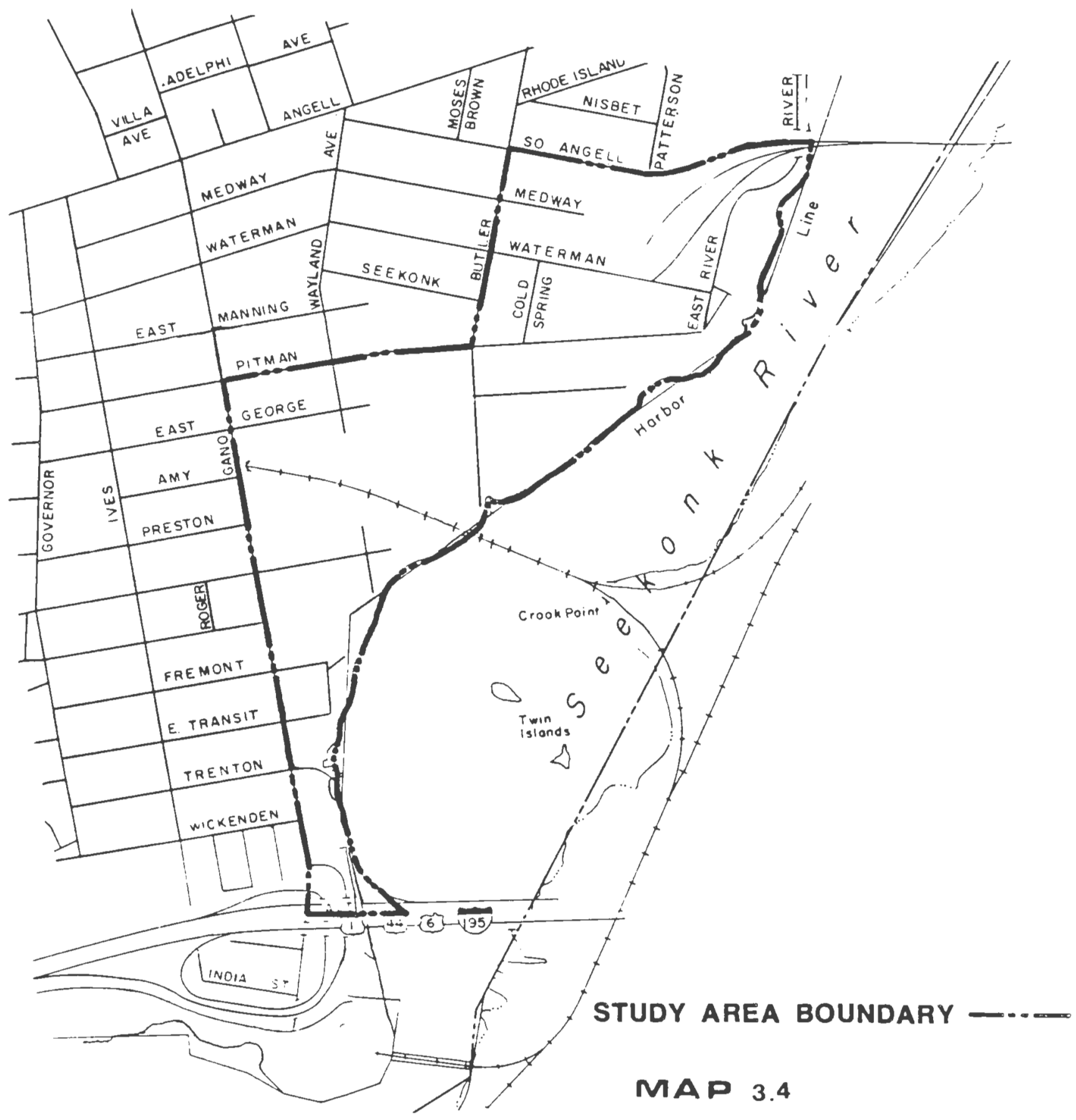

LOWER RIVER SECTION 
understand the socio-economic differences between them. Unlike the other two Waterfront studies that were considered in the previous chapter, the Seekonk Waterfront has a significant amount of residential development. Therefore, land use planning in this area should not only reflect the needs and goals of the City at large, but should reflect a sensitivity to the needs of the existing population.

The demographics of the three study sections reveal distinct populations in each study section. The three demographic elements are reviewed below.

1. Population: Current population figures reflect a decline in population throughout the study area since 1950. The most significant decline in population was experienced in the Fox Point neighborhood, or the Lower River section of the study area. A general decline in population is consistent with national trends of moving away from the city. However, the large difference between the three neighborhoods in the level of out-migration may best be accounted for by different levels of urbanization. Levels of out-migration in each neighborhood correlates with the level of density and urbanization located there. 
2. Income: Average income also differs between sections on the Seekonk River. As presented in Figure 3.1, median income

Figure 3.1: Median Household

Income by Neighborhood, 1989

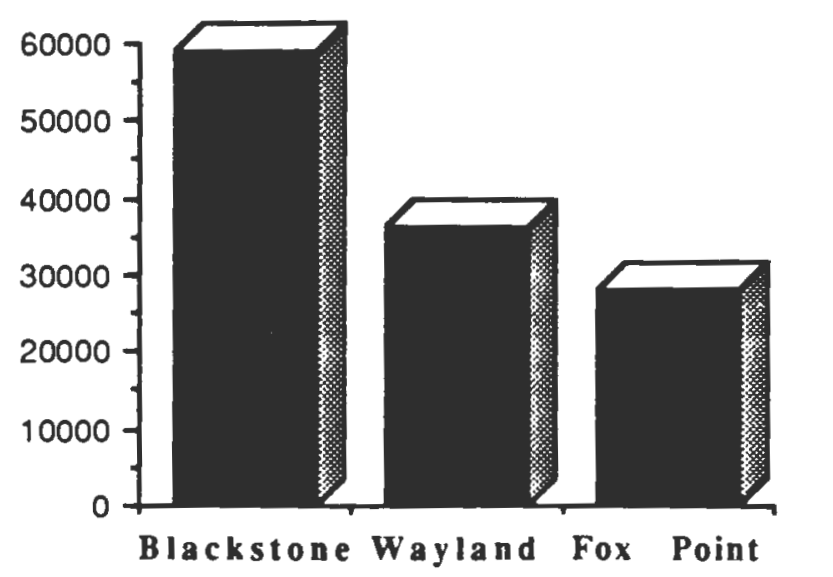

Source: Housing Study for the City of Providence, 1990

levels are highest in the Swan Point/Butler Hospital section and lowest in the Lower River section. The Blackstone neighborhood had the highest median family income level in the City in 1989.

3. Age: The estimated average age of each section of the Seekonk River study area exceeds the average age of the City overall. The City's average age was estimated at 37.4 in 1989. The Swan Point/Butler Hospital section had an estimated average age of 42 . The River Avenue section also had an estimated average age of 42 in 1989, while the Lower River Section had an estimated average age of 39.3. These estimates reflect an increase in the average ages in the areas since 1980, and are consistant with the rising age in the City overall. Reasons for such increase is likely to be different between the three study sections. The age upswing within the Swan 
Point/Butler Hospital section may simply be a symptom of the extremely high cost of housing there. Housing within the area may simply have become unaffordable to younger families. In the other two study areas, however, rises in age may best be accounted for by the relatively lower costs and higher availability of housing for senior citizens.

4. Ethnic Composition: The Seekonk River waterfront has a highly diverse ethnic mix reflected in three general categories: white, black and other. A large "other" category is made up primarily of the large Portuguese population in the area. There is a large presence of minorities in the three neighborhoods overall which make up $45.5 \%$ of the population along the Seekonk River waterfront.

This diversity is not uniformly distributed along the waterfront however. Figure 3.2 shows the ethnic composition of the individual waterfront sections based upon school enrollment.

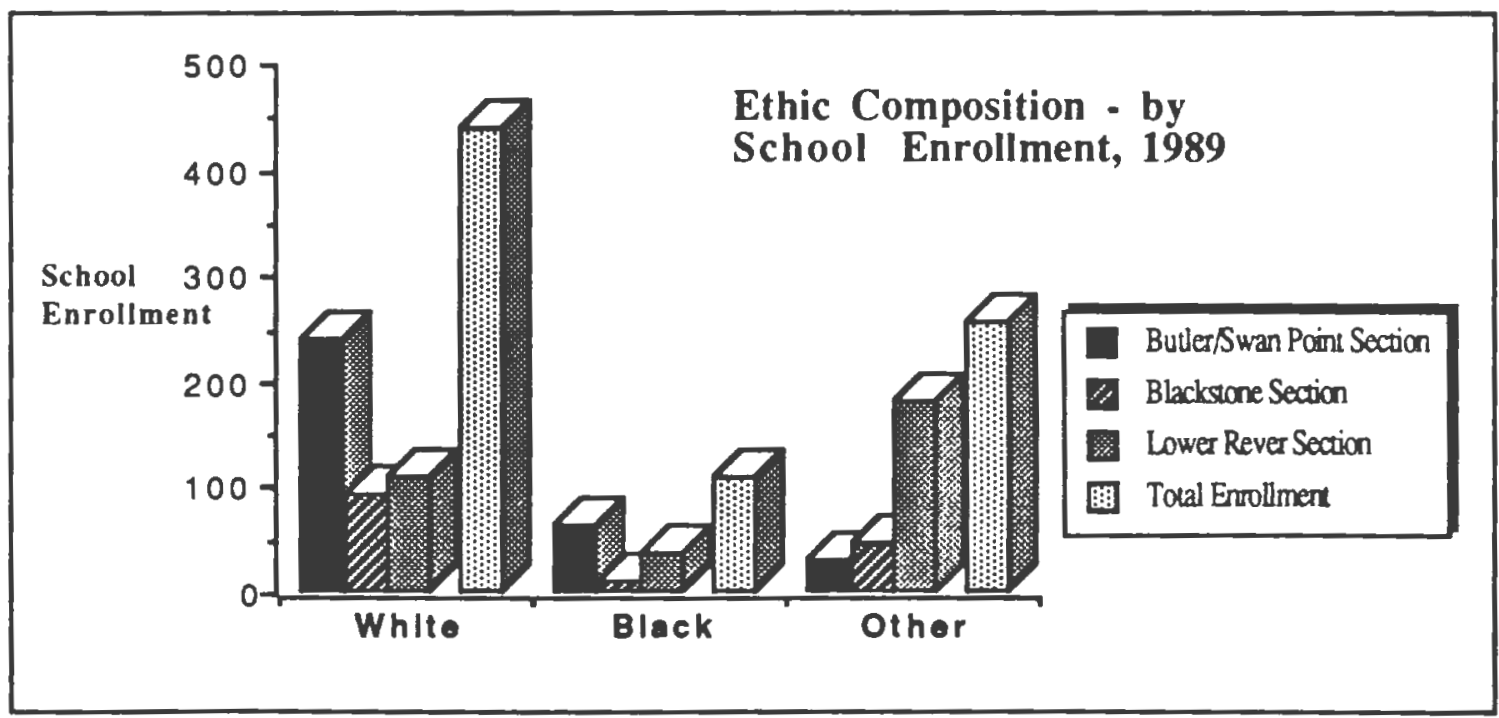

Figure 3.2

Source: Housing Study for the City of Providence, 1990 
This information suggests that while the population in the study area is diverse, individual neighborhoods have a distinctly different ethnic mix. The greatest diversity exists in the River Avenue section made up primarily of the Wayland neighborhood. However, the Swan Point/Butler Hospital section, consisting of part of the Blackstone neighborhood, as well as the Lower River section, consisting of part of the Fox Point neighborhood, does not have a significant ethnic mix. These areas are represented by a significantly larger white population in the Swan Point/Butler Hospital section, and a significantly larger Portuguese population in the Lower River section.

\section{b. Environmental Constraints}

Providence is a highly developed area and is not self-sufficient in its ability to draw needed resources, such as drinking water, from the environment. It is totally dependent upon manmade systems to bring water and eliminate wastes. This has divorced the City from the natural constraints which maintain ecological balance. The result has been a number of environmental problems which are presenting serious problems to future planning. In the future, the City will experience increasing pressures to retrofit its land uses to interact more effectively with the natural environment in which it exists.

The protection of surface water, ground water and vegetation, the use of natural and manmade filtering devices such as wetlands and 
biofiltration techniques as well as the protection of open space, will all contribute in the future to maintain the health and safety of both local residents, and the many others affected by the environmental conditions of the area.

The protection of natural systems along the Seekonk River Waterfront should be provided for in land use planning by the City. Therefore, an inventory of existing environmental conditions in the study area has been prepared and presented below.

1. Water Resources: Map 3.5a shows the groundwater and surface water areas in the Seekonk River Study Area. Groundwater assets are not utilized by the City for public use. Much of the water which would naturally enter the groundwater system in this area is blocked by impermeable surfaces such as streets, parking lots, and urban soils. Therefore a great deal of water is swept into the harbor without entering the groundwater system where some filtering might take place. Although the groundwater along the Seekonk River Waterfront is not used for any municipal purpose, the quality of water is impacted by the existing urban environment. The poor quality of water entering the bay from this area is, along with runnoff all along the City's waterfront, the most significant contributor to the poor water quality of the Providence harbor.

Flood hazards are a problem along the entire waterfront. The major problem areas are found in the Lower River Area. Map 3.5b presents floodplain areas as identified in Floodplain insurance maps. Water quality and the presence of floodplains are significant variables when identifying appropriate land uses in the area. 

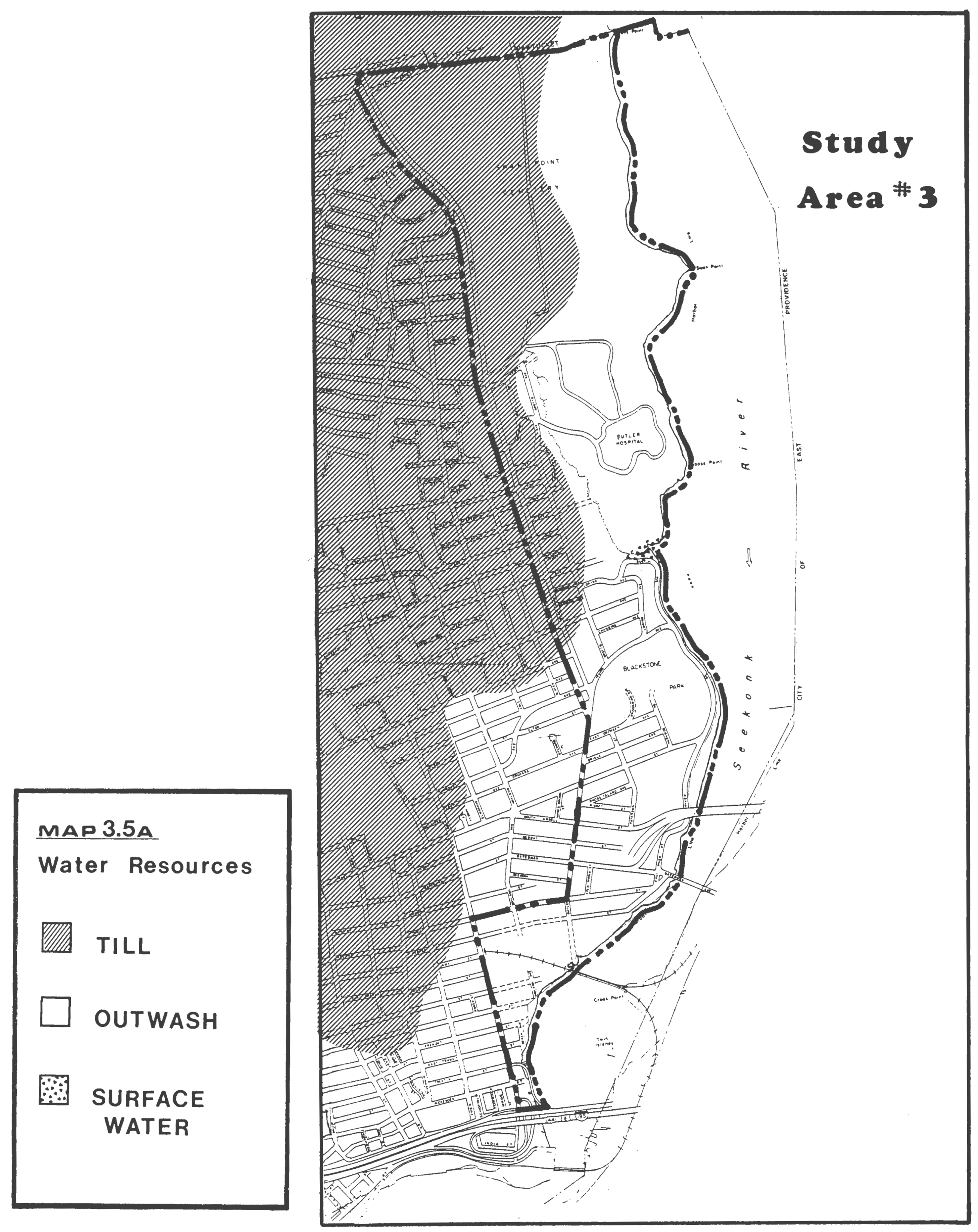


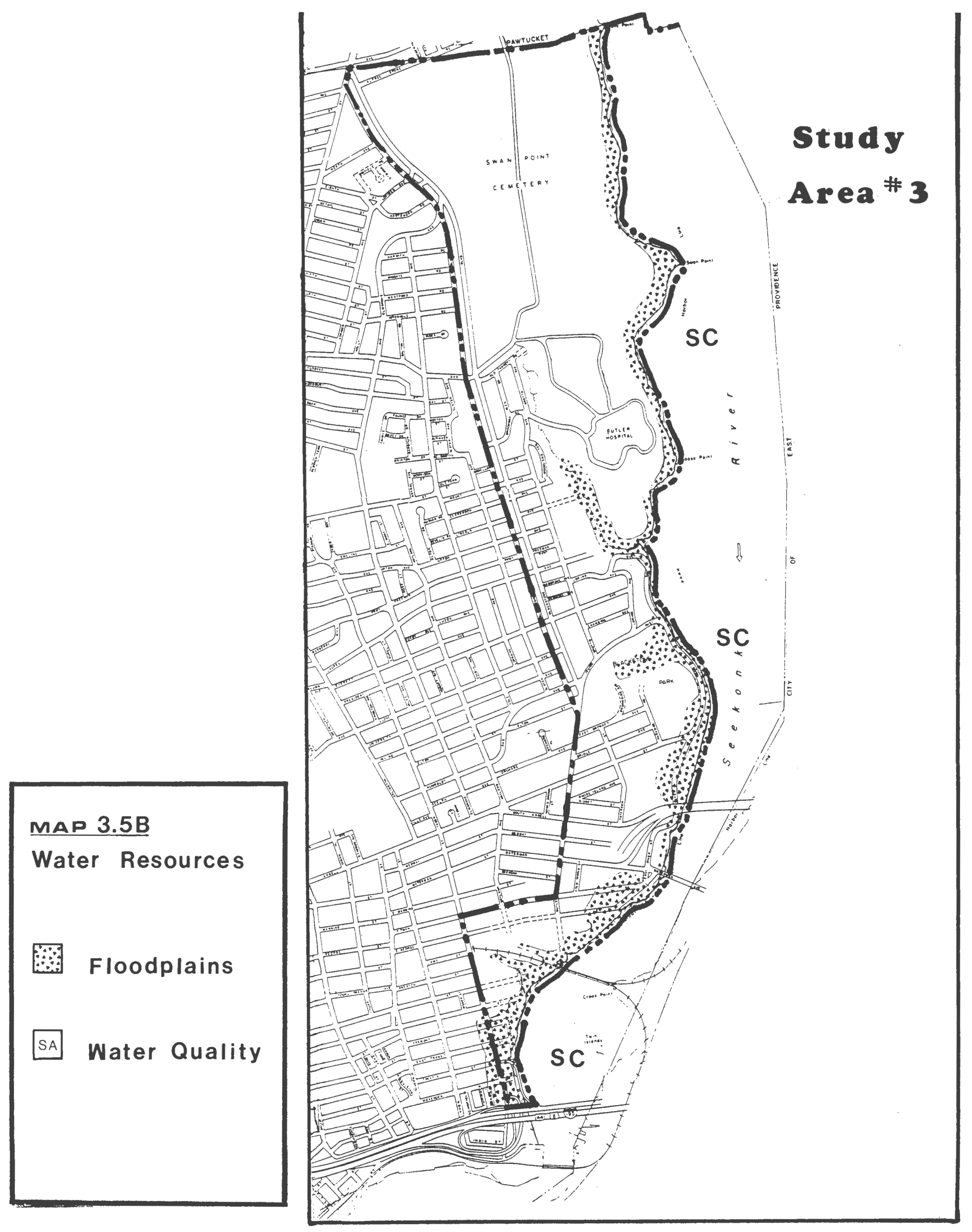


2. Soils and Topography: Soils in the study area consist mostly of Udorthents-Urban Land Comple (UD). Other soil types found within the study are include Merrimac-Urban Land Complex (MU), Hinckley Gravelly Sandy Loam (HKC), Hinckley Gravelly Sandy Loam, Hilly (HKD), Windsor loamy sand (WGB), and Woodbridge Fire Sandy Loam (WHA). These soils generally do not provide any severe constraint to development. However, HKD soils, found along the immediate waterfront in the northern areas of the study area as well as the WGB and HKC soils are prone to erosion, as can be seen by visual inspection of the HKD soils, and therefore can cause problems during development. The permeability of WHA soils found within parts of the study area is slow in the substratum, Therefore, runnoff is slow and there is a tendancy for seasonally high water tables. The UD soils found in the southern areas of the seekonk waterfront need on-site investigation to determine actual conditions due to the variability in the make up of these soils.

Topography in the study area is generally slight to moderate. However, slopes directly adjacent to the river are generally severe. Erosion along the riverfront is a constraint to future development. Land uses appropriate directly adjacent to the river, where these extreme slopes exist, exclude conventional development and other uses contrained by extreme slopes or erosion. Passive land uses would best suit these waterfront areas.

3. Vegetation and Wildlife: The Department of Environmental Management has stated that there are no known rare or endangered 
species living directly along the Seekonk River waterfront. There are several species of rare birds which live in and around the Providence Harbor, however, nesting sites have not been found along the Seekonk River. There are several forested areas along the Seekonk River waterfront abutting the dense residential and commercial development. The majority of this area is located in Blackstone Park and in Swan Point Cemetary. The remaining vegitated areas within the study area include small forested areas within the Swan Point/Butler Hospital Section, several small areas abutting the Richmond Square commercial development, and vacant land within the Lower Seekonk River Section north of the rail lines.

4. Noise: The impact of noise levels in the neighborhoods of the study sections is a significant consideration in maintaining quality of life there. Measurement of noise levels for analysis and planning are generated through decibel readings. Noise levels in natural environments generally measure between two and three decibels. The urbanization of these areas and the introduction of vehicles, regularly increases noise levels in the same area to approximately 65 decibels. Noise levels can have a negative impact on the health and hearing of individuals exposed to certain levels over an extended period of time. Generally, 65 decibels is considered the highest desirable level of noise while 70 decibels is considered to be the critical point of concern. The noise standards maintained by the City of Providence is presented in Figure $\mathbf{3 . 3}$.

Noise levels within the study area are a concern due to the existence of residential dwellings adjacent to highly utilized transportation 
routes. The roads of most concern regarding noise levels include: Gano, Pitman, Butler, Waterman, and South Angell.

Figure 3.3 : Providence Noise Standards

\begin{tabular}{|cll|}
\hline $\begin{array}{c}\text { Decibel } \\
\text { Level }\end{array}$ & Standard & Required Actions \\
\hline DNL<65db & Acceptable & No Remedy Required. \\
\hline DNL 65-75db & $\begin{array}{l}\text { Normally } \\
\text { Acceptable }\end{array}$ & $\begin{array}{l}\text { Barriers or Special } \\
\text { Construction Required. }\end{array}$ \\
\hline DNL75db & Unacceptable & $\begin{array}{l}\text { Required Construction } \\
\text { Costs are Cost Prohibitive. }\end{array}$ \\
\hline
\end{tabular}

Source: Provldence Comprehenslve Plan, 1989.

Noise levels at key intersections were estimated using a nomigraph during the preparation of this document and actual field readings were taken at high traffic periods to substantiate those estimates.

The results of this study are summarized in Figure 3.4 which outlines the noise impacts along the major roadways in the study area. Average decibel levels during peak traffic times exceeded 65 decibels on all roadways with the exception of Blackstone Boulevard. However, with the exception of one roadway, averages did not exceed the desirable level by more than 2 decibels. 


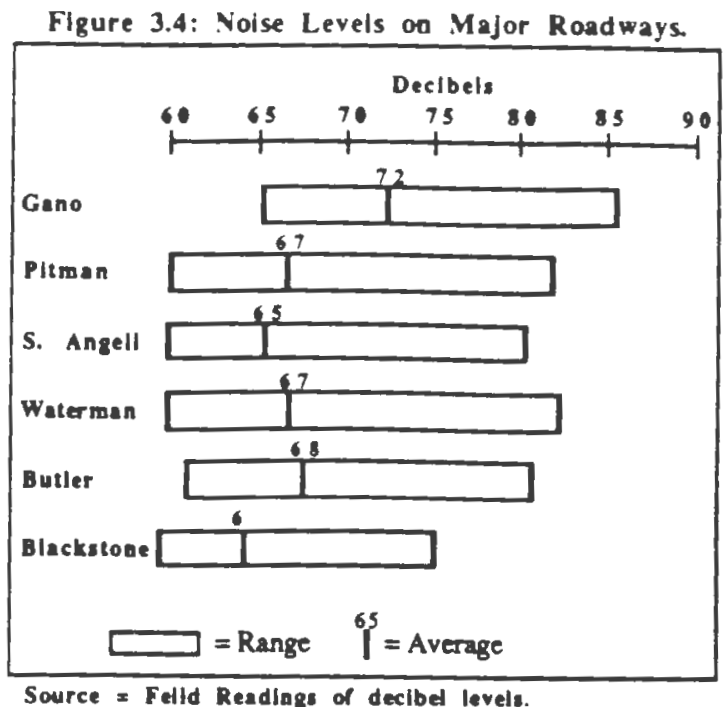

Further, the range of noise levels varied significantly with much of the range falling below 65 decibels. However, conditions on Gano Street where significantly different. A greater mix of trucks, smaller building setbacks, background noise from route 195, and high traffic volumes created an average noise level on the roadway of 72 decibels. The range in decibels consistently remains above 65 decibels and exceeds as much as 85 decibels.

6. Air Quality: There are no existing land uses which cause significant negative impact on the quality of air in the City or elsewhere. The primary negative impact on air quality within the area results from automobile emissions. High traffic volumes with consistent stops throughout the Lower River and River Avenue sections add to the problem. Reductions in the negative impacts may be accomplished through a reduction in the number of stops required in traveling in the area as well as the quantity of vehicle trips through the area. 
7. Hazards: There are no significant hazards within the Seekonk River study area. However, there are several areas where a potential hazard may exist. The most significant of these is the old abandoned Railroad tunnel extending under the east side from the Lower River section. The tunnel is presently in poor condition and is used for shelter by homeless individuals. The old rail line is a health threat to individuals, in particular youths which play in and around the tunnel. Crime, aesthetics, and health are all potentially impacted by the current condition of the rail line.

Shoreline areas with extreme contours and potential for erosion provide a potential hazard to pedestrians. Access to steep shoreline areas is presently obtainable through Swan Point Cemetery and conditions are potentially hazardous to pedestrians walking along the rough pathway there.

The Bascule Bridge, the old rail crossing from the Seekonk River section also provides a potential threat. Although the channel is navigatable, the bridge provides an unnecessary obstacle to passage and a potential hazard to water travelers.

\section{c. Land Use Inventory}

1. Overview of Land Uses: The Seekonk River is the most diversified land use area on the Providence Waterfront. While the other areas of the waterfront are used primarily for industrial and commercial development, the Seekonk River Waterfront hosts a mix of land uses including single and multi-family residential, 
commercial, open space, recreation, and institutional uses. Existing land uses along the Seekonk River waterfront are presented in $\mathbf{M} \mathbf{a p}$ 3.6 .

Figure 3.5 summarizes the major land uses on the Seekonk River. Although each study section differs significantly in its land use composition, the most dominant land use found within the study

Figure 3.5:

\section{Land Uses Along the Seekonk River}

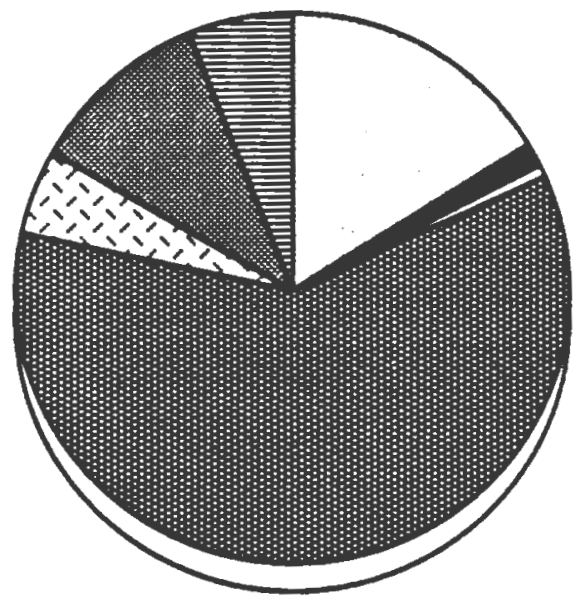

Residential (16.13\%)

CommercialMunufacturing (1.51\%)

Parking (.71\%)

E. Covemment/institutional (60.08\%)

D $\operatorname{Vacan}(4.94 \%)$

9 Parks Recreation (10.58\%)

E Transportation/Utilities (6.05\%)

Source: Providence Tax Assessor's data, 1990.

area is government/institutional uses. However, Swan

Point Cemetery and Butler Hospital, falling in one section, account for most of the land area dedicated to these uses. As a result the character of each section and the disfunctionalities experienced within them vary. The following discussion reviews the basic land use configuration of each section, and then identifies the disfunctionalities discovered during the investigation of the waterfront. 


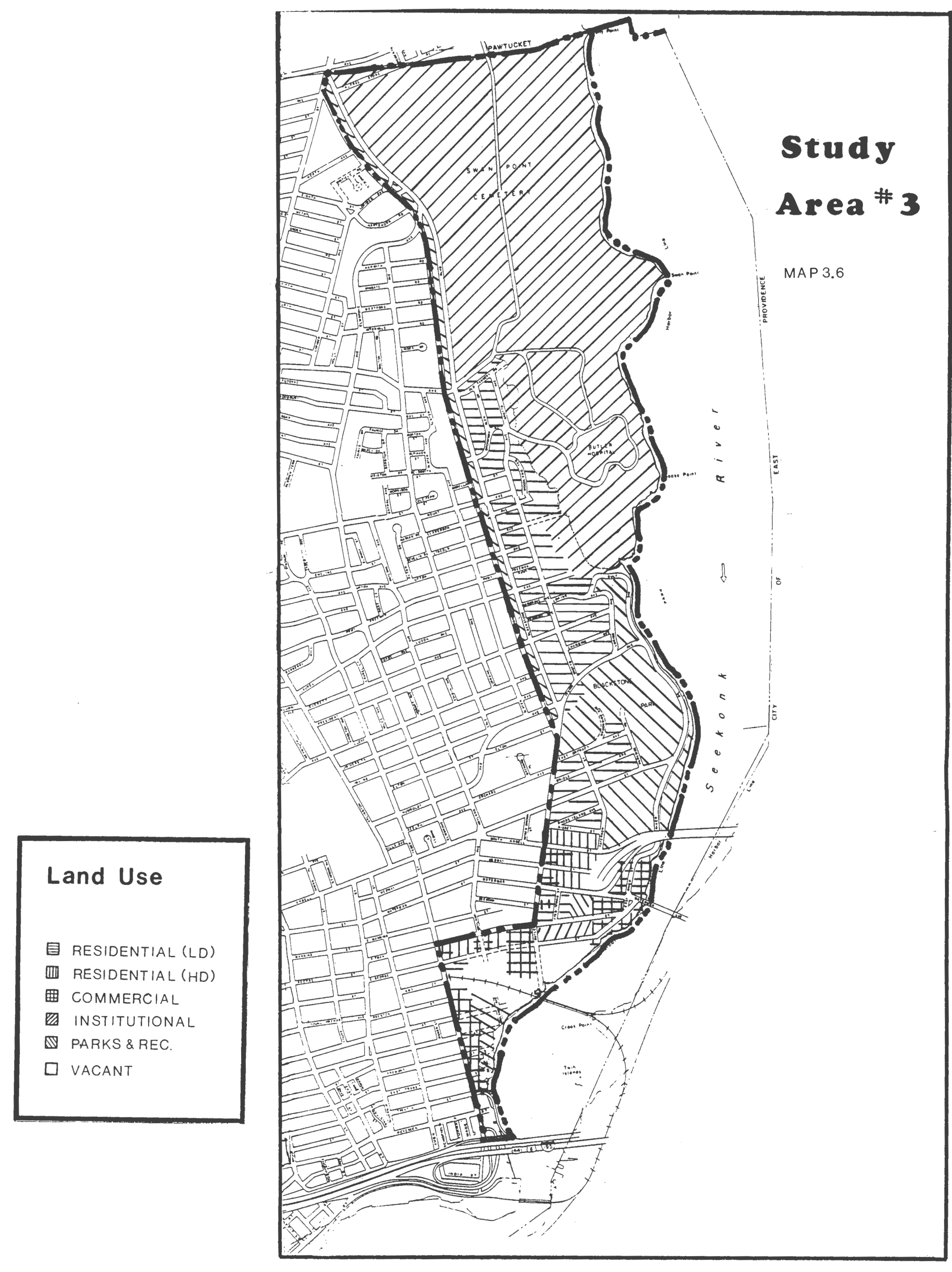


2. Swan Point/Butler Hospital Section: This section, presented in Map 3.7, consists mainly of residential and government/ institutional uses. Land uses in this section of the study area are well suited to each other, even if they are not best suited to the waterfront. The mix of single family residential uses with the large institutions linked by a large boulevard/park system creates an attractive, quiet and highly desirable residential neighborhood. There are no serious land use conflict here yet there is one quite obvious disfunctionality. Virtually the entire waterfront along this section is blocked from public use and access, and is not used in any manner by the institutional uses there. This leaves a significant portion of waterfront area with no functional relationship to the water.

3. River Avenue Section: This section, presented in Map 3.8 has a greater mixture of land uses compared to other sections in the area. It is also host to the most disfunctional land use problems.

The River Avenue section is made up of a mix of high and moderate density residential, commercial, and institutional uses, as well as a highly utilized circulation system. Lot sizes are smaller than in the Swan Point/Butler Hospital section, land values are lower and there is a significantly greater urban atmosphere. However, there is a significant presence of park and open space land use which successfully offers an alternative to the urban climate of the area.

Although land uses are very mixed and have little buffer inbetween them, there are surprisingly few land use conflicts. The co-existance 


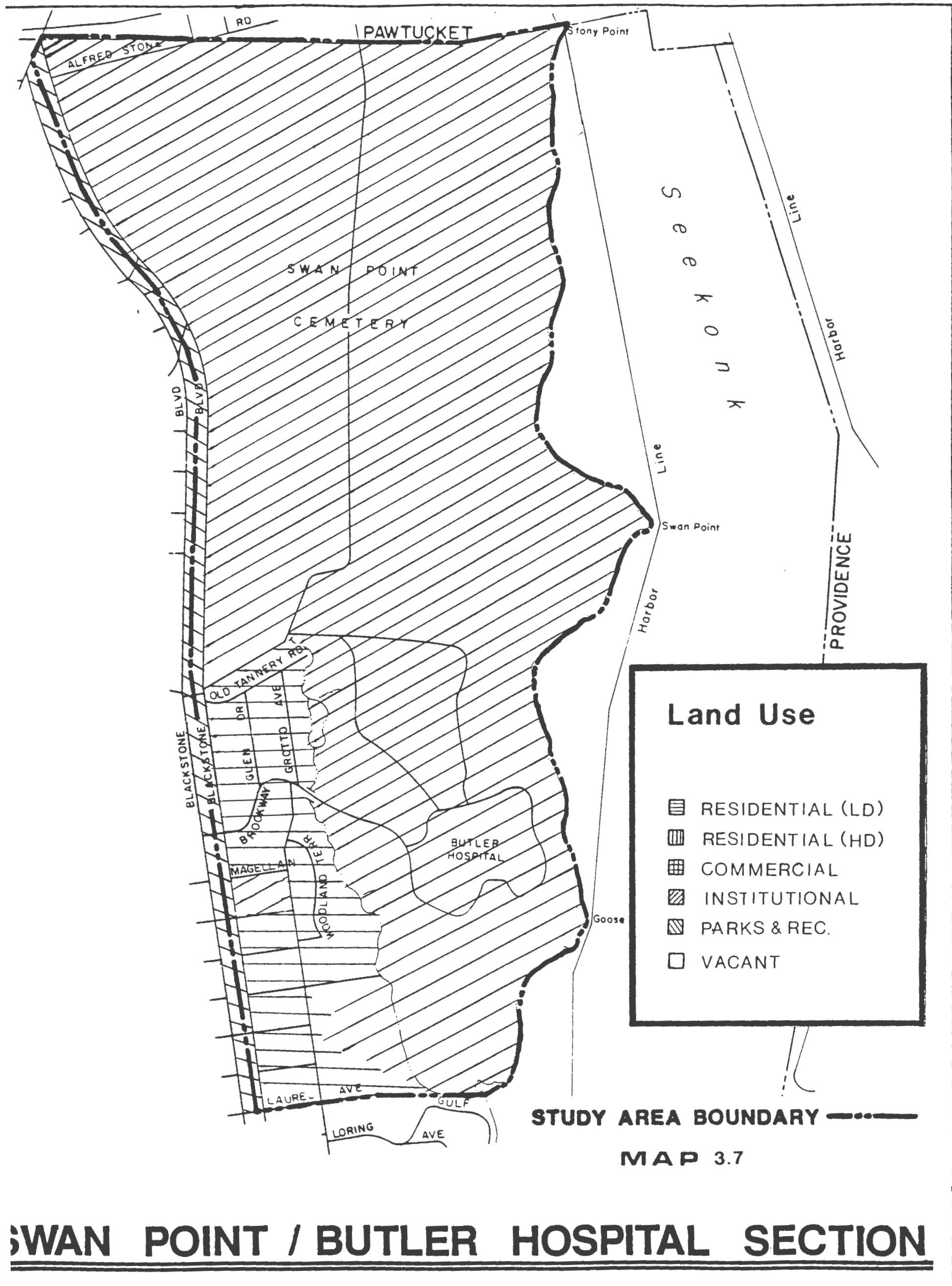




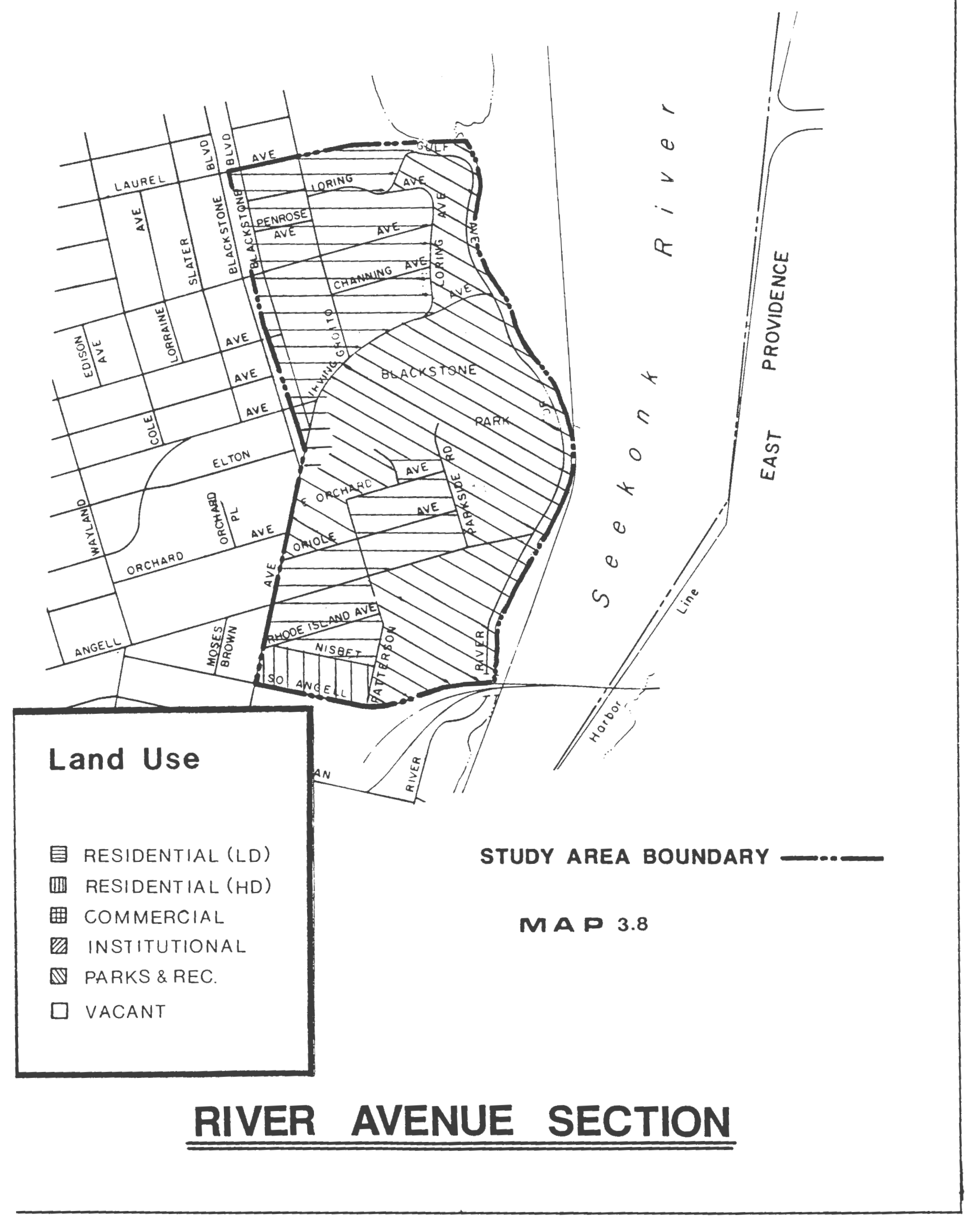


of commercial and residential uses seem to blend in most areas. The one exception exists on Pitman Street where conflicts between commercial and residential uses are quite apparent to the observer.

Also apparent to the observer is the inappropriate circulation system within the area. Waterman and South Angell Streets are used as arterial roads and this creates conflicts with the residential uses in the area. A second disfunctionality in the land use of the area corresponds with that found in the first section. Although the Blackstone Park waterfront offers valuable waterfront access, the non-public areas of the waterfront, made up of the commercial uses in Richmond Square, offer no degree of public access to the waterfront and have no functional relationship to the water.

4. Lower River Section: This section, presented in Map 3.9, is mostly vacant. Of the 58.31 acres of land in the Lower River Section, Gano Street hosts a single strip of commercial and residential uses. The remainder of the section is open space.

Although much of the land between the commercial land uses on Gano Street and the Seekonk River are designated as recreational, the commercial strip creates a visual barrier to this facility. The high volume of traffic on Gano Street and the small number of parking spaces cause additional problems. Further, although the land is directly adjacent to the river, there is literally no direct, indirect, or visual access to the water due to the berms created to fend off flood waters. The result is very low use of the facilities for its intended purpose and leave only one section of the entire 


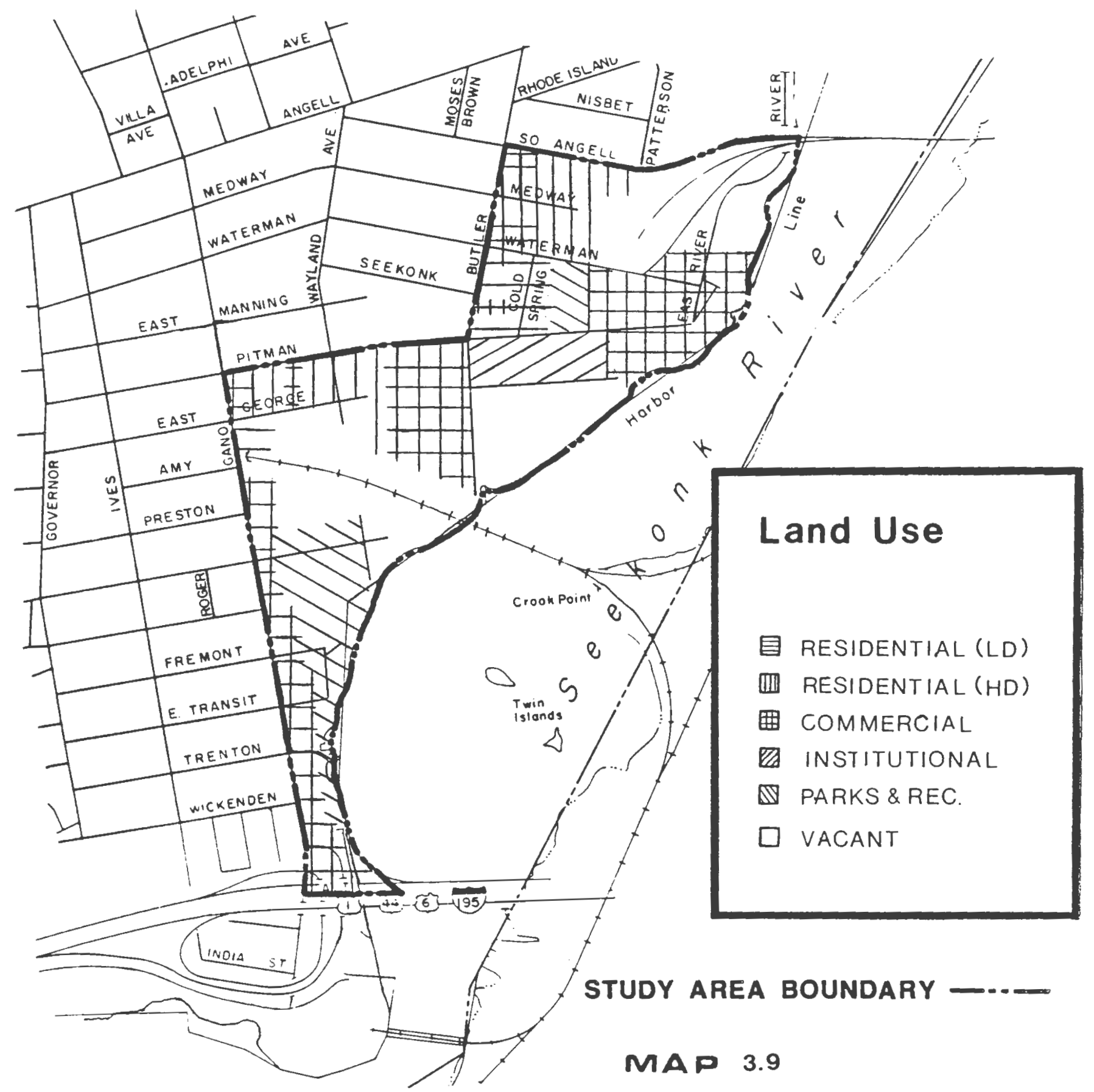

LOWER RIVER SECTION 
waterfront, Blackstone Park in the River Avenue section, as the only waterfront area with public access and any water related usage.

There are also several land use conflicts in this section. The commercial, recreational and circulation uses are land use "strips" which do not support each other. A high volume of traffic along Gano street also creates conflicts with the surrounding residential uses and creates a physical barrier to the use of the waterfront park.

The commercial strip conflicts with the park system as well. No integration of the two uses exists creating a threefold problem. First, visiual identification of the park is obscured which makes the park less noticed and less attractive to potential users. Second, the existence of the commercial strip makes the park less safe due to its visual isolation from the Street.. Finally, the commercial strip makes access to the park difficult to locate and utilize. There is only one entrance with very little parking and inadequate signage.

\section{d. Circulation}

There are three categories which define the use and importance of roads. These three categories include:

(a) Local Roads: Roads having an emphasis on land access;

(b) Collector Roads: Roads having a relatively even balance $\mathrm{b} / \mathrm{w}$ local and arterial functions; and

(c) Arterial Roads: Roads having an emphasis on a high level of mobility for thru traffic movement. 
There are six major roadways in the Seekonk River Study Area which serve as collector and arterial roadways. These include Blackstone Boulevard, Butler Street, South Angell Street, Waterman Avenue, Pitman Street and Gano Street. Peak traffic volumes at specific points along these roadways are presented in Figure 3.6.

Figure 3.6:

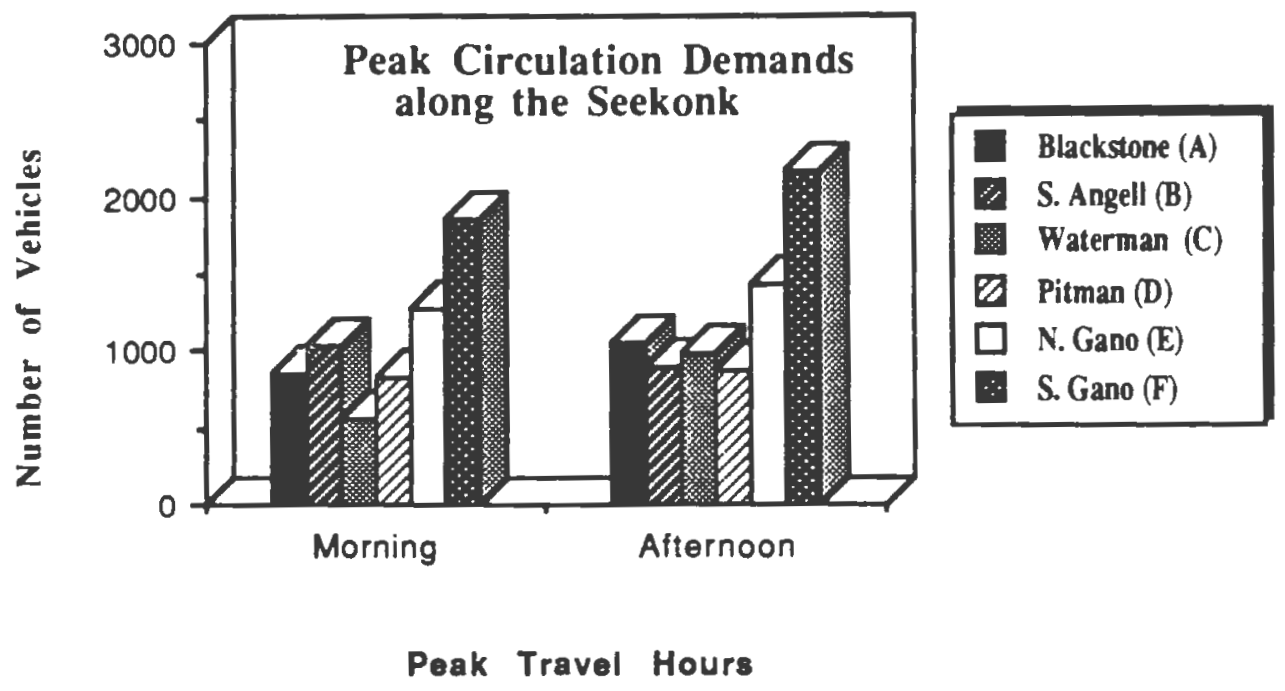

Source: Traffic Counts, Rhode Island Department of Transportation, 1989.

These roadways are normally used as collectors, however, during commuting hours, they are heavily used as commuter routes with a high level of thru traffic. The most significant impact on the area is on Gano street which is highly overutilized, resulting in negative impacts on circulation, neighborhood character, noise level and environment. Although peak traffic volumes create problems on other roads in the area, Gano Street experiences the greatest negative impacts. 
e. Economic Activity

Figure 3.7 presents an inventory of existing businesses on the Seekonk River Waterfront, their activity, and their relationship to the water.

Figure 3.7: Inventory of Waterfront Business, 1990

$W=$ Water-dependent; $\quad E=$ Water-enhanced; $\quad N=$ non-dependent

Occupant

Activity

Water-Dependency

Gano Street:

H.V. Collins

M\&S Auto

Central Meat Market

Blakes, LTD

New Beginnings

Local IUOE - 57

Viola Construction

K. of C.

Professional Offices

Animal Clinic

Construction

$\mathrm{N}$

Auto Sales, Service N

Retail/Wholesale N

Restaurant E

Retail Bookstore N

Institutional $\mathrm{N}$

Construction N

Civic Group E

Periodontics N

Vetinary N

Pitman Street:

Professional Offices

Professional Offices

IGA Foodstore

Medical and Law

$\mathrm{N}$

Business Office

$\mathrm{N}$

Retail Sales

$\mathrm{N}$

Salvation Army

Institutional

Richmond Square:

Achievment Group, Inc

Business Office

$\mathrm{N}$

ADR, Inc

Business Office

$\mathrm{N}$

Aeronet

Business Office

$\mathrm{N}$ 
AIB Chapter I

Amni America, Inc

Atlantic Consulting Group

Bentley Consultants

Borden, Inc

CAD Cam

Cayer Prescott Associates

Cresco

C A Group Public Relations

Church Real Estate

Claim Strategies

Cemeacs

Communication Concepts

Communication Art Group

Con Test

Corporate Associates

Crossland Properties

Daedalus

Dale Carnegie Training

Dawson Communications

Drake and Paulhus

Drug Treatment of RI

Elder Care Resources

Ferreira/Peters, Inc

Fund Consultants

Gibraltar Corporation

Gnoccis Cafe

John R. Gilman and Assoc.

Gregary Ware

Cayer Prescott and assoc.

Real Estate Advisors, Inc

Watlow Infrared

Offtech, Inc.

New England Clearwater

Hale Sun Industries

Harbour Software

Health Initiatives Corp.

Heyco Metals

HIA Incorporated

Home Fashions

Incutech, Inc.

Insurance Co. of America

Intrn'l Health Specialists
Business Office N

Business Office N

Business Office N

Business Office N

Business Office N

Business Office N

Business Office N

Business Office N

Business Office N

Business Office N

Business Office N

Business Office N

Business Office N

Business Office N

Business Office N

Business Office N

Business Office N

Business Office N

Business Office N

Business Office N

Business Office N

Medical Office N

Community Service N

Business Office N

Business Office N

Business Office N

Retail Sales E

Business Office N

Business Office N

Business office $\mathrm{N}$

Business Office N

Business Office N

Business Office N

Business Office N

Business Office N

Business Office N

Business Office N

Business Office N

Business Office N

Business Office N

Business Office N

Business Office N

Business Office N 
Intrn'l Sourcing and Mrktg

Keystone Mortgaging

$\mathrm{K}$-tronincs

Lindsay Claim Services

Loflin Group

Howard Macmillan

Marc Richmann

Micro Source

MMS International

National Investment

Nester, Inc

N.E. Clear Water

Northeast Design Group

Northeast Financial

Offtech, Inc

Pheonix Mutual Life Insur.

Physicians Planning Services

Powers Associates

Proxis, Inc

Quest for Excellence

Rehabil and Re-employment

Research of Jamestown

R.I. Steel Sales

R.I. Steel

Edward Rouslin, CPA

Sackett Assoc.

Sabell \& Raciti Assoc.

Stanelun Assoc

State Mutual Life

Sun Microsystems

George Tinyk and Assoc.

The Learning Connection

Transtech Capital

U.S. Properties Incorp

The Warren Company

Guy J. Wells, Attorney

Vaillant Electric

Roy Weston, Inc

Window Concepts
Business Office N

Business Office N

Business Office N

Business Office N

Business Office N

Business Office N

Business Office N

Business Office N

Business Office N

Business Office N

Business Office N

Business Office N

Business Office N

Business Office N

Business Office N

Business Office N

Business Office N

Business Office N

Business Office N

Business Office N

Business Office $\mathrm{N}$

Business Office N

Business Office N

Business Office N

Business Office N

Business Office N

Business Office N

Business Office N

Business Office N

Business Office N

Business Office N

Business Office N

Business Office N

Business Office N

Business Office N

Law Office N

Business Office N

Business Office N

Business Office N 
Blackstone Boulevard:

Professional Office

Medical

$\mathrm{N}$

f. Historic Preservation

Figure 3.8 lists all sites along the Seekonk River waterfront that are of concern for historic preservation. Most of these sites fall north of Pitman street. Preservation of these sites and the creation of an historic district on Blackstone Boulevard is a goal of the Providence Historic Preservation Society. The number of sites of historic concern here and the historic character which they bring to the neighborhoods, will tend to add to the permanence of existing land uses.

Figure 3.8: Inventory of Proposed Sites

for Historic Preservation.

\# = Proposed for nomination to the National Register.

* = Listed in the National Register, either individually or as part of an Historic District.

Location Site (Year built)

$\begin{array}{ll}\text { \#Blackstone Avenue: } & \\ & \\ 21 & \text { Joseph Moss House (1895) } \\ 35,37 & \text { Morton and Waldron Houses (1881) } \\ 51 & \text { James P. Simmons House (1880) } \\ 55 & \text { Charles H. Reed House (1875) } \\ 87 & \text { Samuel P. Taber House (1937) } \\ 95 & \text { Theodore F. Low House (1963) } \\ 97 & \text { Franklin L. Hathoway House (1870) } \\ 129 & \text { Henry V. A. Joslin House II (1909) }\end{array}$




$$
\begin{array}{r}
145 \\
203 \\
249 \\
255 \\
* 345 \\
* 585 \\
* 585
\end{array}
$$

Butler Street:

163

271
Ashbel T. Wall House (1917)

Prescott O. Clarke House (1896)

Briggs-Samuels House (1915)

Michael Feeney House (1880)

Butler Hospital (1844)

Swan Point Cemetery (1847)

Trolley Shelter (1904)

Pitman Street No sites

Gano Street: No Sites

Waterman Street:

331

229
American Emery Wheel Works $(1898,1909)$

Mutual Fire Insurance Co. Building (1948)

Medway Street: No sites

Cold Spring: No Sites

South Angell Street:
$* 110$
$* 161$
*201
*220
*231
*245-257
*263-273
*283-297
*303
*312
*321
*369-371
*385-395
*403
*614

Lorenzo Sears House (1891)

Christopher A. Pierce House (1870) 
Rhode Island Avenue: No Sites

Parkside Street: No Sites

Channing Avenue:

Gulf Street: No Sites

Angell Avenue:

613

631

646

Oriole Avenue:

15

54

67

East Orchard:

30

51

65

75

Irving Avenue:

16

98

227

290

Grotto Avenue:

$11,15,19$

125

137

Loring Avenue:

40

83

\section{President Avenue:}

99

166
John F. \& William S. Slater House (1867)

John A Sutton House (1884)

John F. \& William S. Slater House (1867)

Nightingale-Cranston House (1868)

Elliot Flint House (1904)

H. E. Walker House (1915)

Lincoln School (1913, 1957, 1968-70)

Emest F. Salisbury House (1925)

Dr. Herman C. Pitts House (1930)

David P. Moulton House (1922)

Frank K. Rogers House (1890)

The Washington Apartments (1913)

Erastus Walcott House (1880)

Frank N. Maclead House (1915)

J. Parker Ford Houses (1913)

Donald S. Babcock House (1928)

Frank Mauran, Jr. House (1929)

Bermard R. Zeman House (1942)

Charles A. Russell House (1925)

Donald E. Jackson House (1912)

Joseph B. McIntyre House (1912) 
Penrose Street: No Sites

Laurel Avenue:

\section{g. Waterfront Access Points}

Map 3.10 shows existing areas of public access in the Seekonk River Study Area. Access includes waterfront areas with direct public access to the waterfront, indirect public access, visual access only, and areas with no access. Of the 16,368 linear feet of waterfront land along the Seekonk River, only 4200 feet can be considered accessible to the public at this time. This area is found on River Drive, in Blackstone Park where indirect access to the water is available from the road. The Narraganset Boat Club maintains a small dock and launch on this road, however, public access is not provided. Therefore access in this area is limited to indirect and visual access only.

Further access, approximately $3600 \mathrm{feet}$, could be added to the existing access by utilizing land in the Lower River Section between Interstate 195 off ramp to Gano Street and Richmond Square. This land is presently used for either recreational facilities or is vacant land. Present commercial development along Gano Street, and the presence of a berm along the waterfront, provide an obstacle to physical and visual access. 


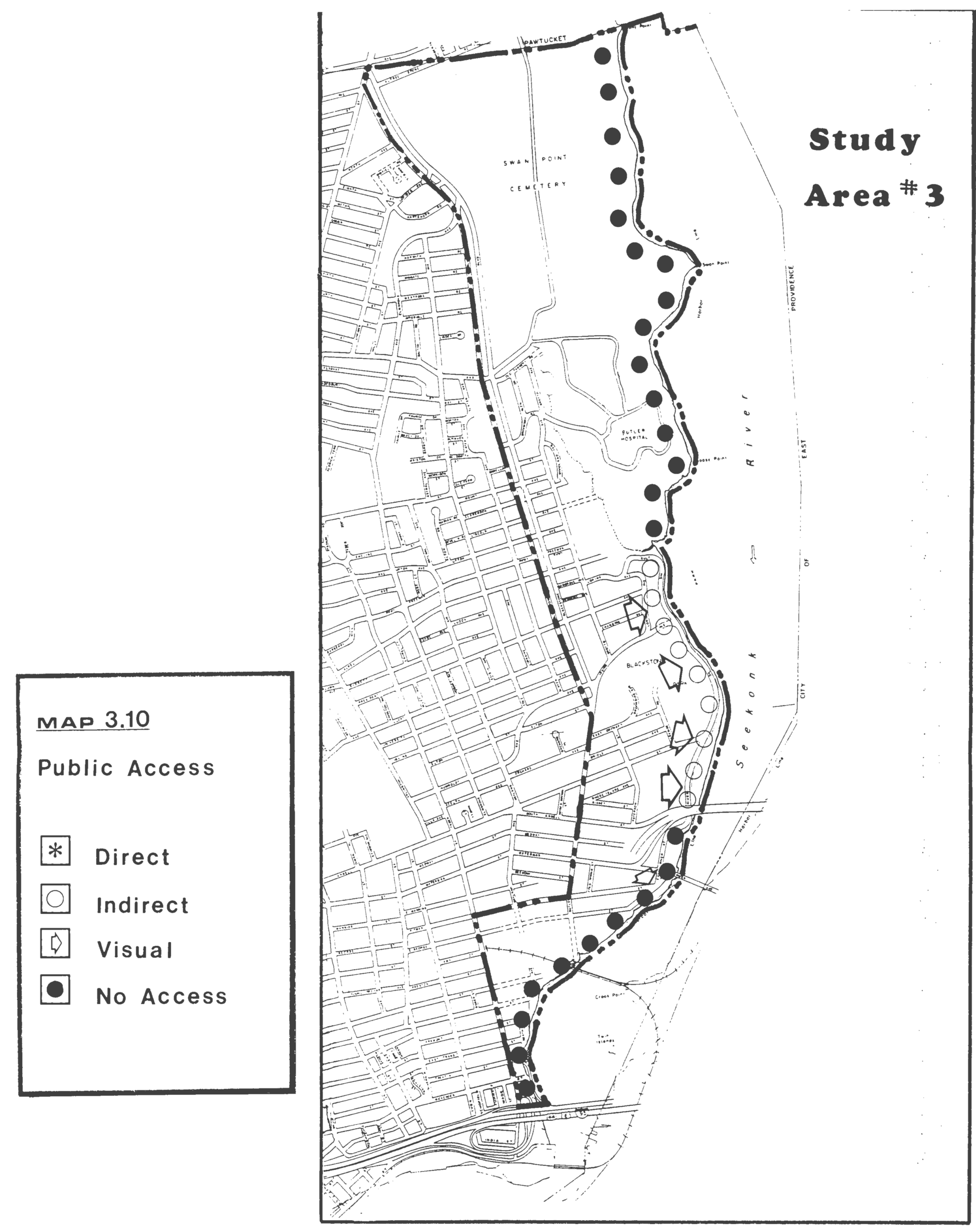


A footpath exists along the waterfront from Pawtucket line south to River Avenue. This land is State owned, yet no right of way exists for public access to this path, and once accessed, traveling is difficult and perhaps dangerous. This path falls within a floodplain and the topography directly to the inland side of the path is extreme in most places. However, areas do exist where right of ways could be placed to establish public access points to the water.

The remainder of the Waterfront, the land within Richmond Square, offers no access to the water. Commercial development in Richmond Square provide obstacles to all types of access. Although some visual access is possible from a parking lot placed directly on the waterfront, there is no provision for public visual access.

\section{h. Infrastructure}

Water Lines: Water to the Seekonk River Area is provided by lines running directly from the Scituate Reservoir. According to the Providence Water Supply Board, most of the lines through the Seekonk River study are the original lines and are over sixty years old. However, these lines are adequately meeting the needs of the City at this time and no major plans exist to upgrade the lines.

In the Lower River Section, where the greatest potential for future development exists, the same general conditions prevail. The existing cast iron pipes are larger than presently needed. No flow tests have been conducted in the Gano Street area, however, tests have been done in the India Point area where water lines enter the 
Lower River Section. These tests, conducted in 1987, showed a yield of 1190 gallons per minute, which is more than adequate for present needs. However, planning for any significant development in the Lower River Section should include flow tests along Gano Street to determine the adequacy of the pipes in delivering the needed water supplies to proposed developments.

Sewer Lines: Sewer lines along the Seekonk River provide service to $100 \%$ of the Seekonk River area. All lines are tied directly to the Field's Point Treatment Facility.

Sewer lines along the River have an average age of approximately 100 years. Most of the existing lines were placed in 1880 . These lines are, however, in fair condition and according to the Providence Department of Public Works, are providing adequate service to the area. The major problem with the existing lines is their age and deteriorating condition. Many of the lines are made of clay, are out of line and have frequent breakage. Therefore, frequent piecemeal repair work has been needed to maintain service. There are no current plans to replace these lines in the near future.

Electric: Electric Power is provided to the Seekonk River study area via lines entering the waterfront from various locations. The Manchester Street plant, located in the Downtown Waterfront study, is the closest facility to the study area. However, this facility contributes only minimally to the available power supply on the waterfront. The largest point of supply to the area is from an 
electric plant in Woonsocket, Rhode Island. Other lines enter from East Providence, Pawtucket and from the Manchester Street plant.

The majority of the lines servicing the study area are underground and are considered to be in good condition. The existing service is considered adequate to meet existing demand and into the near future. However, a $\$ 6$ million dollar upgrade is underway in the Manchester Street plant which will more than double the available energy supplied by that facility and ensure greater supply to the waterfront area as well as to the rest of the State.

Gas: The waterfront recieves gas supplies from pipelines running under the Providence Harbor from East Providence. The lines cross the harbor at several points. A single pipeline crosses the Seekonk River one mile north of the Henderson Bridge and was installed in 1970. Three other pipelines cross in the Port area and were installed in 1955. All of these lines are protected against corrosion, monitored every other month, and are considered to be in good condition. Local lines in the Seekonk River area are also considered to be in good condition and are monitored regularly.

The existing lines are considered to be adequate to provide for present and future demand. However, the Providence Gas Company's Engineering Department stated that the development of any land uses other than light commercial and residential may require upgrading to the present capacity of lines in the area. 
i. Plans, Policies and Zoning

1. Residential Development on River Avenue:

New residential development has been proposed along River Avenue near Richmond Square. This development would take the form of a high-rise residential structure. Preliminary approval has been given and the Planning Department expects this project to be built.

2. Multi-use Development on Gano Street:

Various plans for the development of land along Gano Street have been considered. Mixed-use development of the area has gained greatest acceptance, but no construction has begun within this area. 4. Other Plans - Bike Route, Street expansion:

Other plans along the waterfront include the State plan to expand the existing bike route, now extending from Colt State Park to East Providence, through the east side of Providence. Also, the City of Providence has considered extending several roads in the Lower River Section to accommodate future development.

5. Jurisdictions affecting the Waterfront:

The primary agency effecting land use along the Seekonk River other than the City of Providence is the Coastal Resources Management Council (CRMC). CRMC has regulatory powers over all waterfront land directly along the coast. Any development directly 
along the waterfront must be approved by CRMC and, if it includes use of waterways by the Army Corps of Engineers (ACE). The Department of Environmental Management (DEM) also has jurisdiction in protecting environmental resources on and around the waterfront. The State of Rhode Island can also be considered as having significant jurisdiction in the area due to the large amount of land in the area owned by the State.

Planning for the waterfront should take the interests of these agencies into consideration as well as those of neighboring communities.

\section{Zoning Changes:}

The City zoning ordinance has recently been updated and waterfront zones have been established on the Seekonk Waterfront. These new zones have been established in an attempt to provide greater protection for waterfront needs and to greater flexibility and authority to future waterfront policies and plans.

\subsection{TRENDS AND ISSUES}

a. Neighborhood Trends and Issues

1. Swan Point/Butler Hospital Section:

This section of the waterfront is best defined as a low transition, or slow changing area. The existing conditions in the area tend to resist transition. In fact, transition in the area would likely diminish 
present conditions. This section has quality housing, sufficient open space, and adequate circulation.

The issues which will effect this area in the future are (1) recreational uses of the waterfront, and (2) the need for improvement to the existing infrastructure.

DOT has plans to place a bike route through this section. Initial plans intended to create a bike route directly along the River, however, later revisions of the plan have placed bike lanes on both sides of Blackstone Boulevard. CRMC's study of the Providence Harbor identified the Swan Point section as an ideal location for the creation of a public boat ramp.

\section{River Avenue Section:}

This area is best defined as a moderate transition area. Waterman, South Angell and Pitman Streets combine to form a zone of overlapping uses. With competing uses and highly utilized circulation routes, there is less stability in current land uses and, in fact, transitions can be seen along Pitman Street where several conversions from residential to commercial have recently taken place. With recent trends toward greater commercialization, greater residential density, and higher circulation demands, this area will continue to tolerate transitional pressures.

Blackstone Park, one of the most stable locations in the area, still has some transition potential. At present, its recreational use is limited to generally local use. However, the location of the park along the 
Seekonk River suggests that this park has value as a community resource and future improvements to improve access may be forthcoming.

Another plan which places transitional pressures on this area is the DOT's plan to create a bike route through the area. This bike route will result in physical changes in the area as well as creating a significant level of bicycle traffic.

\section{The Lower River Section}

This section is best defined as a high transition area. With the large area of land which is functionally unused, the level of planning proposals to use the land, trends for greater commercial development, plans for expanded residential development, DOT plan for the extension of the bike route, and increasing stress on the transportation system, land use in this section is highly instable. This section will likely receive the greatest attention in planning efforts during the next few years.

\section{b. Availability of Waterfront Land}

The most significant condition which exists along the waterfront is the lack of vacant land. The demand for waterfront space is the reason for intensive land use planning in the other study areas and why the Seekonk River waterfront is drawing increasing interest for planning and the identification of development sites. This trend is likely to continue and the decisions made by the City now will affect 
the complexion of the Seekonk River waterfront for decades into the future.

c. Availability of Waterfront Recreational Facilities

Although the Seekonk River waterfront has several recreational areas, they are generally poorly utilized due to inadequate or obscure accessibility. Further, with pressures to develop the Gano Street's park areas, much of the available recreational land may disappear.

The recreational facilities in this study area provide most of the City's waterfront recreation opportunities. Therefore the future availability of these resources will grow in importance. Future recreational issues in the study area will likely be focused on the effective use of the land which is available for this purpose. Locating new recreational areas, linking these areas together, and providing good access should be a major planning consideration in future waterfront planning.

\section{d. Protecting the Residential Character of} the Neighborhoods

Residential areas in the Lower River Section lie in a mixed-use area. These areas offer a mix of commercial and residential uses and are more densely developed than other, purely single family residential areas in the study area. The inevitable result of this higher densitymixed use, is a greater amount of vehicle activity. This area is no exception to this rule. However, to this naturally elevated vehicle 
activity, the Lower River Section also tolerates the influx of commuter traffic, which overruns the section during commuting hours. These additional vehicle volumes are not travelers with residential or commercial destinations within the section, and therefore only add to congestion, noise and the general urban environment. This is particularly true on Gano and Pitman Streets. Further development in the area will add to the negative impacts in the Lower River Section. Future development plans need to include plans to mitigate the impacts that high traffic has on the residents in the area.

e. Citywide Demands on Land Use

Studies have suggested the need for more industrial expansion to improve economic conditions. They have recommended the identification of new industrial sites within the City is a major land use pressure at this time. However, this is not likely to influence land uses within study area directly.

Objectives of the City to upgrade and increase housing opportunities will provide the greatest influence on the land use in the study area within the immediate future. Although commercial activity has expanded in the area, economic conditions and zoning will limit the amount of commercial growth.

\section{f. Land Use Demands on the Lower River Section}

As the section of highest transitional potential and the greatest available development land, the lower river section is the location 
where a great deal of integrated planning will need to take place to accommodate a variety of needs. Demands which will need to be addressed in this small area include recreational expansion and improvement, increased waterfront access, circulation improvements, infrastructure upgrades, residential and commercial expansion. Specialized planning in this area will need to take place as well as a high level of intergovernmental coordination to ensure the accomplishment of planning goals.

g. Historic and environmental Preservation

There are concerns that many of the existing environmental and historic features of the Seekonk River waterfront could be threatened by public or private development in the future. Neighborhood residents of the Swan Point/Butler Hospital section are most concerned about this threat. Blackstone Park, Blackstone Boulevard, and other features of the area provide a pleasant residential atmosphere buffered from problems existing elsewhere on the River. It is feared that changes to surrounding areas of the waterfront and plans concerning the section itself, may have negative impacts on living conditions.

Preservation of historic sites along the Seekonk River is being facilitated by preservation groups in the City. The preservation of sites with historic significance will preserve the historic character of the waterfront area.

Environmental preservation will also continue to be an issue on the waterfront. Water quality is already compromised by runnoff in the 
area, and future development will only increase these problems. Therefore, planning policies will need to be improved to allow for greater density while retrofitting disfunctional systems already in place.

\subsection{RECOMMENDATLONS FOR THE SEEKONK RIVER WATERFRONT}

a. Land Use

\section{Promote Multi-use Development in the Lower Seekonk River Section}

Much of the vacant land in the Lower River section is publicly owned. However, acquisition of key properties in the area would facilitate public/private development in the area. Future development includes the extention of roads from Gano Street and the establishment of residential/commercial uses in both State and City owned land. The introduction of a mixed-use development (residential and C-1 uses) would contribute to the diverse needs in the area.

The establishment of a mixed use development would serve several purposes: (a) increase the economic base of the City and the Riverfront, (b) expand the tax base of the City, (c) promote use of the resources and facilities of the City's waterfont, (d) provide better use of vacant land for commerce and residences while expanding recreational and circulation services, and (e) sustain a semi-public atmosphere through the development. 
Proposed development plans define the limits of development at the rail lines, however, expansion of development, south of the rails will assimilate the function of the rail services into the development. A local stop within the development will support localized use of the rail for entertainment and convenience "non-vehicular" cross town travel. Use of the vacant land south of the rail lines will also facilitate the extention of River Road, the establishment of the state planned bike route, and the extention of river recreation and waterfront access.

A redevelopment plan has previously been proposed for the Lower River section which was reviewed in Chapter two. Recommended land use in this area should follow closely with the nature of that redevelopment plan, however, the redevelopment would be most worthwhile in meeting waterfront goals if such development were expanded to include more of the available waterfont land.

\section{Increase Waterfront Access to Waterfront}

As the primary waterfront area providing public access and waterfront recreational opportunities for City residents, study area 3 is greatly underutilized. Every section of the waterfront has potential for greater access in some way.

The Swan Point/Butler Hospital section has a large amount of waterfront which is completely inaccessible. Methods to open this 
up via a right-of-way to the water for a boat launch and for linear waterfront access along the water, should be explored.

The River Avenue section at Blackstone Park also has potential for increased access. Only indirect access to the water is available at this time, but the removal of obstacles to allow better access is possible. Access at Richmond square is functionally blocked both physically and visually, but could be improved:

Access to the waterfront along the lower river section is also blocked. However, providing for this access during redevelopment of the area would be very feasible. Providing access to the waterfront is possible for virtually all of the waterfront along the Seekonk River and should be pursued as valuable resources to the City.

\section{Encourage Greater Water Dependent/enhanced uses}

Water dependent or enhanced uses of the waterfront exist in only one or two locations on the waterfront. Greater functional use of the water will increase its value as a resource. Restaurants, residential units, water taxi's, boat ramps, ferries, marina's and similar uses all benefit from and add value to the waterfront. The development of such uses are recommended all along the waterfront.

\section{Reduce the intensity of traffic within neighborhoods:}

The character of the neighborhoods in the lower river and River Avenue sections have been greatly compromised by the high levels of traffic congestion. Traffic in these sections often create a physical 
barrier to movement, undesirable noise and emissions levels, and a harsh urban atmosphere. Methods to mitigate these problems should be pursued, including the rerouting of commuter traffic around the area via the River Avenue extention proposal.

b. Public Policy/Regulation

\section{Adopt Recommended Waterfront Land-use Map}

Future land-use of the Providence Waterfront is recommended in Map 3.11. Recommended land-use is based upon studies for each area and should be utilized for future waterfront planning, comprehensive planning, capital improvement planning, and policy development. The adoption of this land use map and its inclusion in comprehensive, and capital improvement planning is recommended.

\section{Conduct Special Planning For the Lower River Section}

Special plans should be undertaken before the development of the lower river section. It has not been determined what impact new development will have on the outdated infrastructure servicing the area. Further, the implementation of specific needs in the area to accommodate the various goals will require specialized engineering and/or architectural study.

\section{Include Waterfront Planning in Comprehensive Plan}

The Seekonk Waterfront as well as the the other waterfront areas aresignificant resources of the City and play important roles in its economic, social and cultural structure. Therefore, waterfront planning should be included in the comprehensive plan of the City. 
MAP 3.11

\section{Recommended}

\section{Land Use}

anstitutional

$\square$ RESIDENTIAL (LD)

- Residential (hD)

- commercial

- MIXED USE

7 RECREATION

transportation

$\rightarrow$ IMPROVEMENTS

INDUSTRY

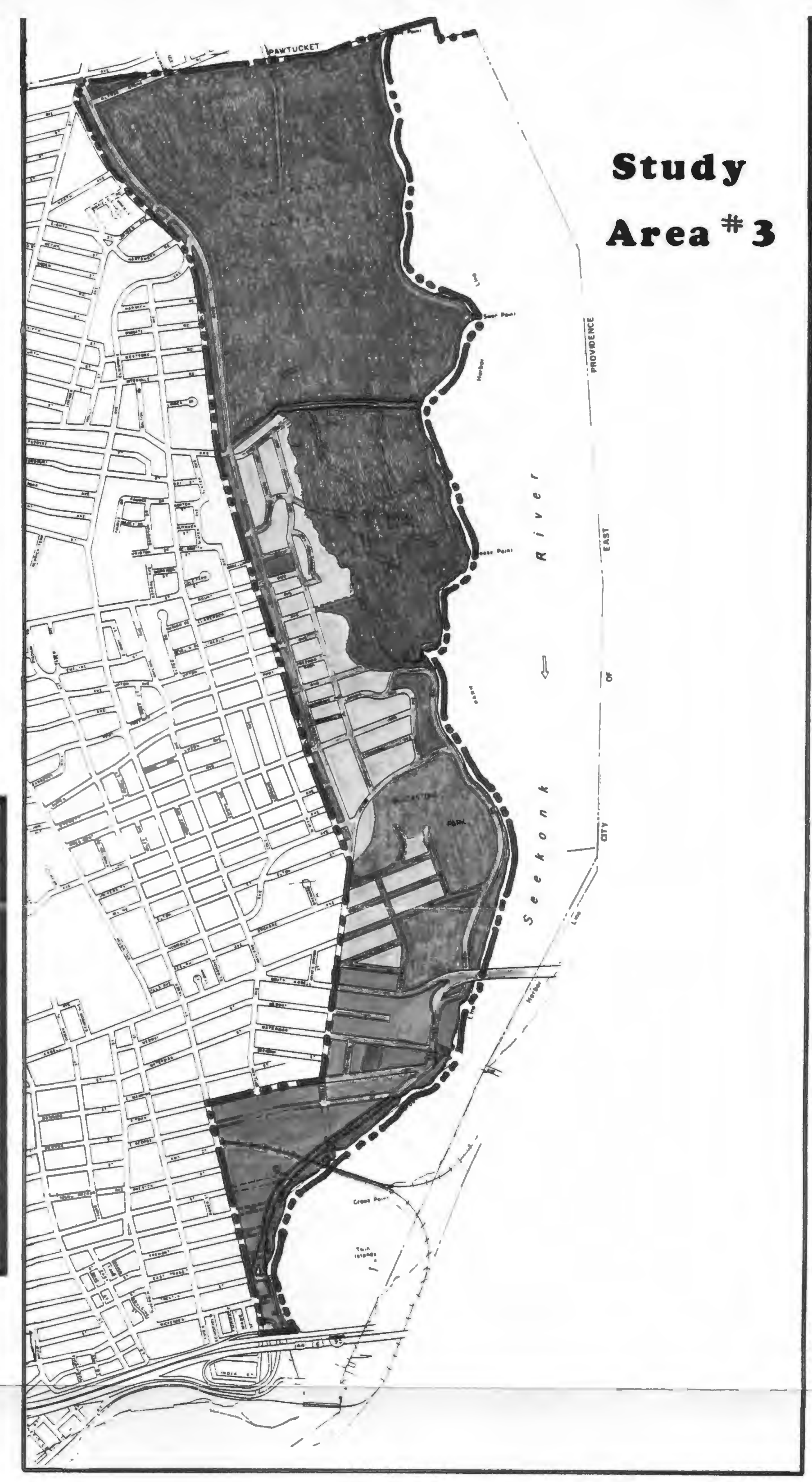


Assimilation of the goals and objectives of this and future versions of the Waterfront Guideplan in the City's comprehensive plan will improve the coordination and implementation of plans, as well as provide public input and support for such planning.

\section{Utilize Capital Improvement Program to Implement Waterfront Improvements}

All planning within the City should be implemented through the City's capital improvement plan (CIP). Waterfront planning should be no exception. Goals and objectives should be sufficiently specific in nature and should be submitted for inclusion in the CIP. This is the only method through which systematic consideration and fiscal support for plans can be given by the City's administrative body.

\section{Support Aesthetic Improvements}

Wherever possible, aethsetic improvements should be supported all along the waterfront. This can be accomplished with great success during the development of open space, the implementation of public improvements, and the upgrading of infrastructure.

\section{Support Historic and Environmental Preservation}

Public policy should encourage the preservation of the historic resources in the study area. Further, policies for the retrofitting of disfunctional runnoff systems as well as ensuring future protection against water quality damage and erosion should be improved and enforced. 


\section{Maintain and Improve Visual Access to Waterfront}

Visual access to the waterfront should improved through the establishment of viewing vistas, removal of sight obstacles, creation of greater access to the shoreline, and the enforcement of low height restrictions on future development projects.

\section{Establish Policies and Identify Sites for Possible Public Marina Development}

There are a number of possible locations which might be suitable for the development of a public marina. The identification of sites and the establishment of policies for its development must be coordinated through the CRMC and must be preceded by the development of a Harbor Management Plan.

\section{Improve Inter-governmental Planning Efforts}

Historically, planning coordination between contingent communities regarding waterfront issues have not been successfully accomplished in Providence. With the variety of needs to be accomplished along the waterfront, the need to coordinate with other communities, the State, and other regulatory agencies need to be carried out effectively. It is recommended that specific individual(s) within the Planning Department be designated as department liaisons with specific agencies outside the City. Coordination of planning with these outside agencies should be pursued and followed by these specific individuals. 
c. Improvements

\section{Include Infrastructure Improvements in CIP}

As stated above, effective planning should be implemented through the City's CIP. Improvements to the study area's antiquated infrastructure system will be necessary in the near future and should be included in the preparation of the Capital Improvement Plan as an upcoming project.

\section{Include Park Improvements in CIP}

Park improvements including linkages, access, vistas, lighting and others should also be included in the Capital Improvement Plan.

\section{Extend River Road from Richmond Square to India Point}

A road has been proposed along the Seekonk River which would extend River Drive. The new road would connect Richmond square with India Point Park and create a linear drive and recreational system along the river. This proposal should be pursued for several reasons. First, such a road would create a by-pass around existing residential areas for travelers going to the Blackstone and East Providence areas. Second, the road will provide the City with an opportunity to move toward a "loop road" for commuters traveling in and out of the downtown area. The objective of such a loop road would be to create lower resistance to travel between the Capital Center Project area and the Seekonk River area. This road would 
utilize existing roads from the downtown through Fox Point and India Point (improvements made as necessary to facilitate smooth flow), and ultimately connect to the proposed road and lead to the Henderson Bridge. The result of such a loop road would be to reduce traffic on local roads in the residential neighborhoods in the east side. Third, the proposed road would significantly increase public access to waterfront recreational facilities along Gano Street and at Blackstone Park where access is limited or discouraged due to physical barriers. Fourth, plans by the State to place a bicycle path through the study area will be efficiently assimilated into development plans. Existing placement of the bicycle path in State planning does not support efficient development of vacant land in the Lower River section. Fifth, the development of a loop road system would create a physical link between the Lower River Section and Downtown which provide economic development opportunities and expand redevelopment interest in the area.

\section{Revitalize delapitaded Rail Lines}

Repair of rail lines running from East Providence, over the Bascule Bridge, through the development area and under the east side into Downtown via tunnel has been proposed. The feasibility of this project has been questioned based on various points highlighted by arguments that the potential revenue generated by the service would not be sufficient to cover capital and operational costs. However, the significance of this project should be measured by the other benefits it would provide to the City other than commuter services. The establishment of efficient "non-vehicular" travel 
services between downtown and the Lower River Section would stimulate local use of the service for convenient cross town travel as well as dining and entertainment during early afternoons and evening. Perhaps the greatest benefit would be found in the long term regional and national perception of the City. Modernization, convenience, and diverse transportation options are attractive attributes for future marketing and economic development efforts.

The implementation of proposed development plans in the Lower River Section offers many benefits. Combined, the recommendations serve to (a) improve circulation on the City's east side, (b) expand active and passive recreational resources, (c) increase waterfront access along the River, (d) Improve the residential quality of east side neighborhoods, (e) Create new residential units, (f) Provide economic growth opportunities, (g) Stimulate greater use of existing commercial establishments and encourage the development of more cultural and entertainment establishments, and (h) Improve the aesthetic value of the Lower River Section.

\section{Create a Public Boat Ramp}

There is currently no public rampalong the Providence waterfront. The establishment of a boat launch could be accomplished along the River Avenue extension, but would be most effective in Blackstone Park or along the northern shore between Butler Hospital and Swan Point Cemetery. This would require the establishment of a public right-of-way. 


\subsection{EVALUATION OF SEEKONK RIVER STUDY}

The Seekonk River waterfront study has identified major planning issues which will affect land use and planning over the next three to five years. Recommendations for the Seekonk River waterfront area reflect current conditions and needs. However, greater planning needs to be done regarding specific areas in this study area. Special studies need to be undertaken to determine the fiscal feasibility of rail revitalization, road extensions, and associated changes/impacts in the Downtown Waterfront Area. The information provided here is sufficient to meet the initial goal of this document; to establish integrated land use planning for the Providence Waterfront. 


\section{Chapter 4:}

\section{PROVIDENCE WATERFRONT RECOMMENDATIONS}


The Providence Waterfront, extending from Cranston to Pawtucket, includes a diverse mix of land uses, conditions, and needs. However, the consolidation of information provided by the various studies and documents outlined in chapters one through three of this guideplan, allow for the consolidation of goals reflecting the needs of all waterfront areas. Although the needs, and therefore the goals of each of the study areas differ, they can be assimilated into four major goals for the waterfront:

1. Strengthen the relationship between waterfront land uses and the harbor;

2. Strengthen the land uses appropriate to each area of the waterfront;

3. Mitigate the negative impacts of development along the waterfront; and

4. Provide integrated, long range planning along the waterfront and with the city at large.

Investigation of the three study areas have provided, to differing degrees, objectives, recommendations and implementation strategies for the improvement of waterfront land use. Major objectives which support the above goals and affect the Providence waterfront overall have been drawn out of individual studies and are presented below. These recommendations for the Providence waterfront are then consolidated into an implementation table which outlines the level of involvement required by the City, and the priority in achieving the objective. 


\subsection{Strengthen the relationship between waterfront land uses and the harbor:}

The land-use to water relationships of primary interest are the industrial uses in the Port area, the commercial uses in the Downtown area and in the Lower River and River Avenue sections of the Seekonk River area, and the recreational/open space uses in the Downtown and Seekonk River areas. These areas have been targeted as having less than desirable functional relationship with the water. The following objectives reflect the need to enhance these relationships.

\section{a. ESTABLISH WATERFRONT ACCESS POINTS ALONG THE PROVIDENCE AND SEEKONK RIVERS}

Each study emphasized the need to provide greater public access in the form of viewing vistas, right-of-way's, removal of access obstacles, increasing types of access at existing access points, and establishing marinas, boat ramps, and other methods of direct public access. The most significant needs for public access points are found in the Port of Providence and along the Seekonk River. Of these two, the Seekonk River area holds the greatest potential for the expansion of public access.

\section{b. STRENGTHEN MARITIME USES OF THE PORT AREA}

Protecting the Port of Providence as a regional point of commerce is an important part of the Providence economy. Investigation of the Port area has shown a movement away from maritime uses. 
Maritime uses of the Port are important to its preservation. The City of Providence should encourage and promote increases in the maritime use of Port facilities.

\section{c. ESTABLISH GREATER INTEGRATION BETWEEN WATERFRONT PARKS}

The availability of waterfront land to establish greater integration between parks is most available where it is most appropriate, along the Seekonk River. The Lower River section has significant undeveloped waterfront land. Appropriate use of this vacant/open space land, and the areas directly adjacent to it, can provide recreational linkages from Blackstone Park to India Point Park. The Swan Point/Butler Hospital section has potential for the establishment of a right-of-way to the water for a boat ramp and for linear waterfront access along the water. Opening up linear access to the waterfront behind Swan Point and Butler Hospital would extend the recreational system extensively and this linear access and boat ramp would be linked to the waterfront recreational system at Blackstone Park.

Objectives of the Downtown and Seekonk River study areas include an integration of existing recreational facilities. Two methods were suggested in these studies which offer opportunity to increase the availability of and access to recreational facilities between Blackstone Park and the downtown. Functional linkages between existing parks can be established through the state planned bike route, the expansion of River Road, and establishing 
greater linear access along the waterfront. Physical linkages can be accomplished through appropriate development and/or improvements of specific land between specific parks to create physical links.

\section{d. DEVELOP A PUBLIC MARINA(S)}

Various studies have identified the development of one or more public marinas along the waterfront as an appropriate use of land in the Downtown and Seekonk River areas. Such a project would serve many purposes for the City including the expansion of recreational uses, greater public access to the water, stimulation of nearby commercial uses, and increased revenue to and promotion of the City. Development of such a marina must include the development of a Harbor Management Plan and approval by the CRMC.

\section{e. PROMOTE WATER DEPENDENT/ENHANCED COMMERCIAL USES ON THE SEEKONK RIVER}

Very little water dependent or water enhanced commercial activity exists on the waterfront. The establishment of a public marina, water taxi, expanded recreational opportunities, revitalization of commuter rail line, and establishment of waterfront zone all contribute to stimulate water dependent and enhanced activites along the waterfront.

Promotion of activities which increase a functional relationship with the water will increase its value to the City as a cultural and environmental resource. An important benefit would include the 
improvement of the residential climate of the Fox Point and Wayland Avenue neighborhoods as a method of turning around recent outmigration trends.

\section{f. ESTABLISH A PROVIDENCE HARBOR MANAGEMENT PLAN}

One of the most important objectives for the Providence waterfront is the establishment of a Harbor Management Plan. Such a plan will provide for the coordination of water and land uses in Providence and establish greater local autonomy in planning for the waterfront. Such local autonomy over the waterfront and harbor will afford the City the opportunity to have greater authority to implement waterfront planning and establish a public marina and boat ramp. It will also provide greater control of water uses in the harbor by the City of Providence.

\section{g. ESTABLISH BOAT RAMP ALONG SEEKONK RIVER}

Studies have noted the lack of a boat launch along the Providence waterfront. The most appropriate location for the development of one or more boat launches has been suggested along Blackstone Park and/or between Swan Point Cemetery and Butler Hospital (with establishment of a right-of-way).

\subsection{Strengthen the land uses appropriate to each area of the waterfront}

Land use changes along the Providence waterfront have created or aggravated conflicts among incompatible land uses. Increases 
have been measured in residential and commercial land uses while industrial land use has declined.

Figure 4.1:

Land Use Change on the Providence Waterfront from 1975 to 1989

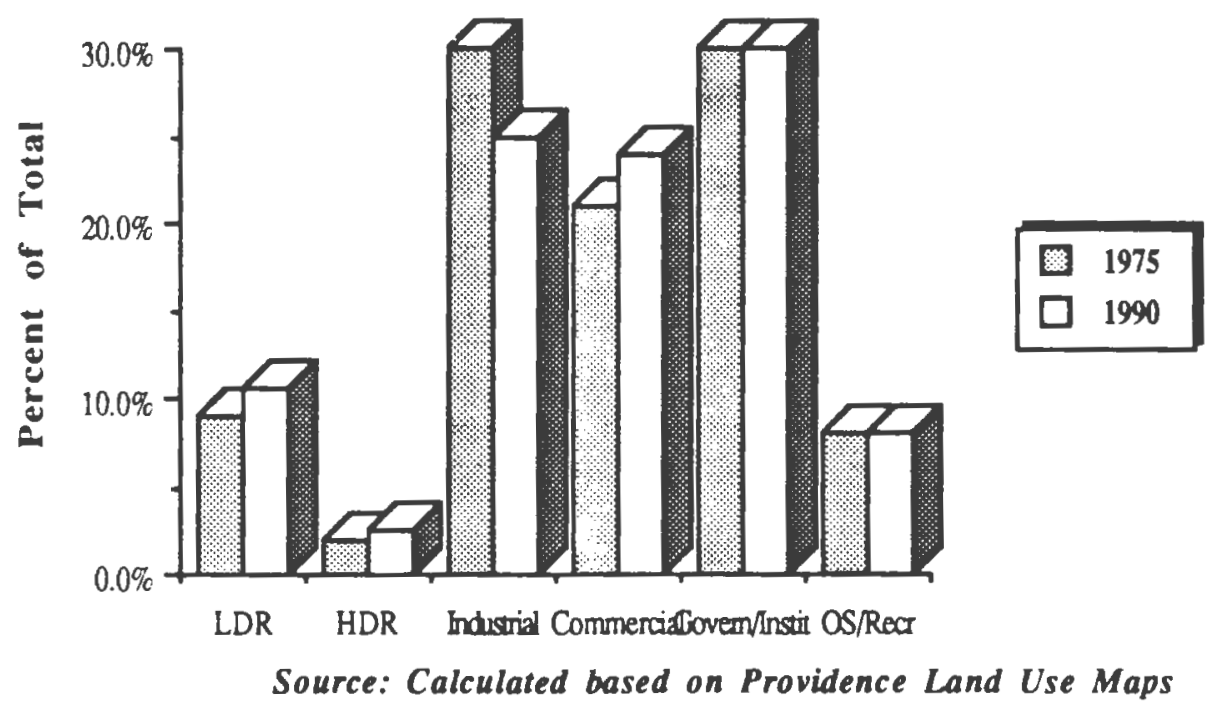

The demand for commercial, residential, industrial and recreation waterfront space encourages a desirable diversity in land use. However, these land uses are not well defined or differentiated in some places on the Providence waterfront. The following objectives are offered to support the strengthening of appropriate land uses. Map 4.1 shows the recommended land use on the Providence Waterfront.

\section{a. REINFORCE INDUSTRIAL LAND USES WITHIN THE PORT AREA}

Investigations into land use in Study area One have shown a weakening of the industrial base of the Port. This weakening has been further exacerbated by a subtle change in the existing 86 


\section{Waterfront Guideplan}
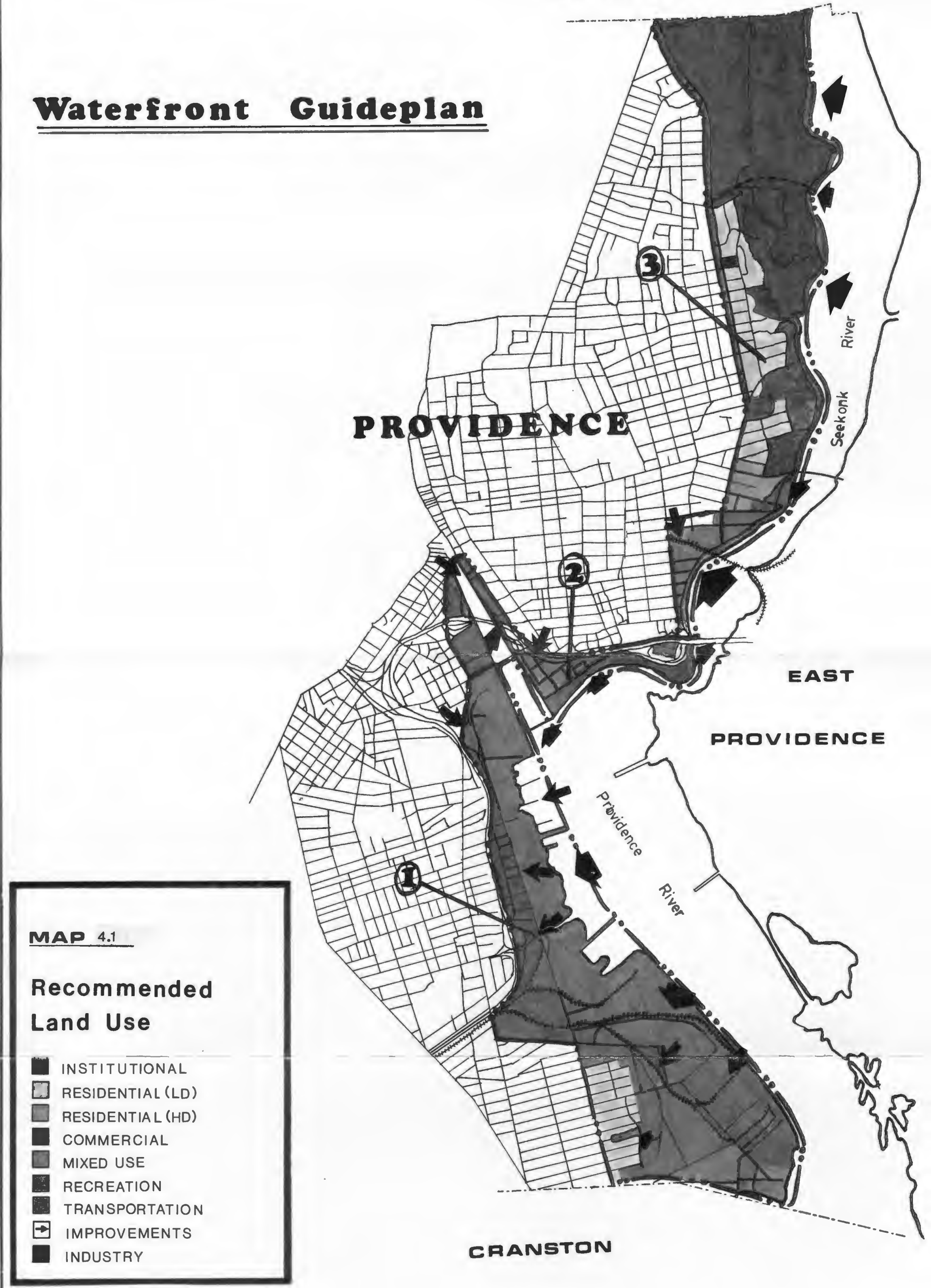
喜
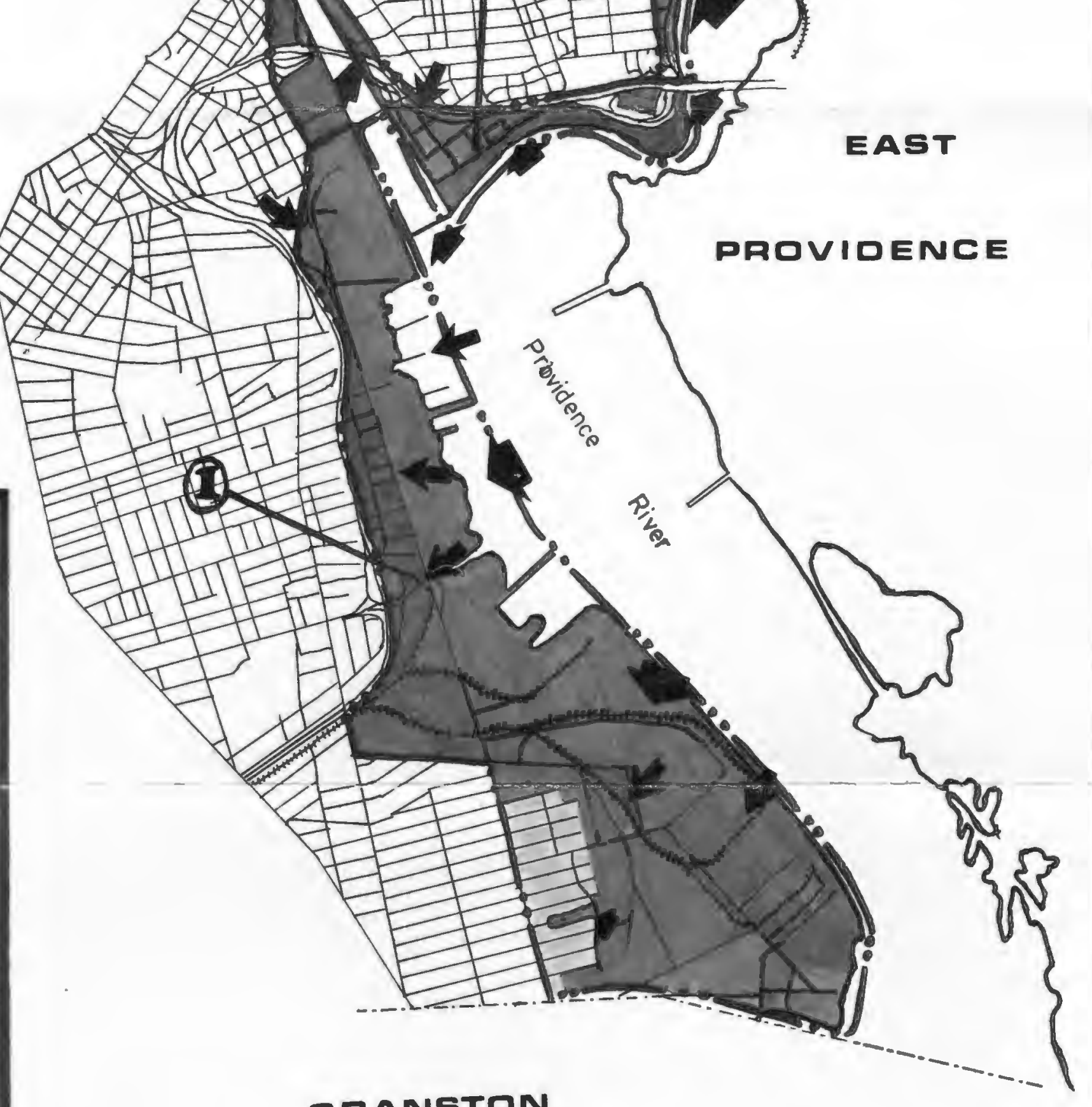

CRANSTON 
industrial uses away from maritime activities. To protect the port as a regional point of commerce and ensure its value to Providence in the future, water-dependent industrial uses should be promoted by the City.

\section{b. STRENGTHEN THE RESIDENTIAL CHARACTER OF THE LOWER SEEKONK RIVER AND RIVER AVENUE SECTIONS}

There have been a number of recommendations made which will contribute to the improvement of the residential character of these neighborhoods. Public improvement to the circulation system is the most important of these recommendations. The implementation of other recommendations affecting the recreational system, development of open space, and improvements to the infrastructure will all contribute to improving the residential atmosphere in the area. These plans should be included in the City's comprehensive plan and in the Capital Improvement Plan.

\section{c. PROMOTE MULTI-USE DEVELOPMENT IN LOWER RIVER SECTION}

Of the total land area in the Lower River section, $36 \%$ of the land is vacant and publicly owned. A great deal of land in the area is owned by the City due to the existence of floodplains. The State also owns land where the old rail line falls. The public ownership of this land prevents their contribution to the City tax base.

The development of this land into a multi-use development can serve many purposes. New residential units will offer greater 
housing opportunities and contribute to the revitalization of the Fox Point neighborhood. Added commercial space will stimulate more activity, making the section more profitable, more valuable in terms of property values, and will create a more secure social environment. This section can also accommodate greater definition of recreational facilities such as the proposed bike path which will complement residential development and the establishment of riverside viewing areas. The extension of River Avenue, including the alteration of the on/off ramps at the Henderson Bridge, linking major circulation system between downtown, I-195 and the Henderson Bridge, would accommodate and support various goals for the planning area.

\section{d. ESTABLISH NEW LIGHT INDUSTRIAL DEVELOPMENT AREA}

The southern portion of study area One offers an opportunity to both expand the industrial facilities of the port area as well as provide an appropriate land use buffer between the existing land uses, non-industrial land uses in the Washington Park neighborhood and across the city line in Cranston. Light industrial development should meet appropriate standards to ensure its function as a buffer area.

\section{e. INCREASE PARK AREAS AND ACTIVITIES AT INDIA PARK}

Various recommendations have been presented for the improvement of park facilities at India Park. Such recommendations as biking and jogging trails, new water and land structures, a waterfront security force, linkage with the 
surrounding recreational systems, as well as increased circulation in the area due to the River Avenue extension, all address needs in the area for greater public use of the park as a community resource.

\section{f. IMPROVE ACCESS AND FACILITIES AT BLACKSTONE PARK}

The Providence Comprehensive Plan calls for the consolidation and regionalization of City parks to derive greater benefit for more of the community's residents. This reflects the isolated nature of available park lands in the City, such as Blackstone Park. Greater physical access to, promotion of, and signage to Blackstone Park should be implemented to encourage greater use as a community rather than a neighborhood park. Further, as a community park, public improvements should be implemented, such as lighting, linkage with other waterfront recreational systems, and increased access to the water, to encourage greater use of the park facilities.

\subsection{Mitigate the negative impacts of development along the waterfront}

\section{a. ESTABLISH AN URBAN IMPACT MITIGATION PROGRAM}

Study of the Port of Providence led to recommendations to have an industrial impact mitigation program. Although the conditions vary between waterfront areas, urban impacts can be found all along the waterfront negatively affecting residential living for residents. The entire waterfront could benefit highly from the 
development of such a program which would manage circulation patterns, monitor air and noise standards, create buffer zones, and establish other methods to increase the quality of City neighborhoods and reduce the negative effects of urbanization on the waterfront. Efforts in this area should be extended into the harbor itself through a Harbor Management Plan.

b. ESTABLISH AN EMERGENCY RESPONSE PROGRAM FOR THE PORT AREA

There are many potential hazards existing within the port facility which hold potential danders for people in and around the area. Port studies have recommended such a plan. The use of a National Oceanic and Atmospheric Administration manual, entitled Oil and Hazardous Substances Planning and Response Considerations (1986), was recommended as a guide to the development of this plan.

c. SUPPORT EFFORTS TO REDUCE THE LEAKAGE OF CONTAMINANTS INTO THE PROVIDENCE HARBOR

The Providence Comprehensive Plan, and other City and State plans, have identified urban runnoff as a serious problem for the City. Although State funds have been invested in the upgrading and retrofitting of runnoff designs in the City, many of the problem areas are City owned and maintanenced points of discharge and will not be part of the project. The City of Providence should support the efforts of the State and other agencies seeking to mitigate this environmental problem. Support should be provided through public policy as well and, where 
possible, through physical improvements to locally maintained discharge points.

\section{d. REMOVAL OF DEBRIS FROM HARBOR}

Debris exists throughout the harbor along all the three waterfront study areas. Expanded usage of the waterfront and water in the future, as well as the improvement of the environmental and cultural quality of the waterfront requires this debris to be systematically removed. Debris removal efforts should be addressed during the preparation of the Harbor Management Plan.

\section{e. IMPLEMENT PHYSICAL IMPROVEMENTS IN ALL AREAS OF THE WATERFRONT}

Physical improvements to the waterfront have ben recommended all along the providence waterfront. Improvements should include waterview vistas, direct access points, Blackstone park improvements, roadway reconstruction and upgrade, recreational linkages, infrastructure upgrades, rail line revitalization, and other recommended improvements. These improvements should be addressed in a systematic manner utilizing the City's capital improvement program.

\section{f. ESTABLISH A LOOP ROAD AROUND SEEKONK RIVER AREA}

As part of the mixed-use development of the Lower Seekonk River, River Road should be extended beginning with the realignment of the on/off ramp of the Henderson bridge into River 
Road. River Road should be extended along the waterfront and link into Gano Street at India Point Park. It should also provide access to and from Route I-195. The establishment of this road will relieve many of the traffic problems in the River Avenue and Lower Seekonk River sections.

\section{g. MODIFY UNATTRACTIVE ASPECTS OF THE NARRAGANSET ELECTRIC FACILITIES}

The narraganset electric facility in the Downtown Waterfront study area has been identified as a major detraction to the waterfront, the downtown area, and to the City overall. Methods to improve the unattrative aspects of the facility will provide a major facelift to the entire area and help promote the waterfront as a commercial and recreational resource.

\section{h. CONSOLIDATE AND REDUCE INDUSTRIAL USES OUTSIDE PORT AREA}

It has been stated in previous studies that the Port area is not being sufficiently utilized for industrial uses. Industrial uses outside of the port area, particurlaly around residential areas and those which are appropriate in the port, should be consolidated and reduced. Industrial use of the Port should be emphasized as the primary industrial location within the City of Provicence.

\section{i. EXERCISE ENVIRONMENTAL REVIEWS ON WATERFRONT PROJECTS}

The Providence Comprehensive Plan states a need for the City to exercize environmental reviews on all developments of 
considerable size within the City. It is essential that such reviews take place along the waterfront. With existing problems in runnoff contamination, outdated infrastructure, noise and air pollution and shoreline erosion, it must be ensured that new developments do not make mitigation efforts more difficult.

\subsection{Provide integrated, long range planning along the waterfront with the City at large.}

\section{a. COORDINATE PLANNING WITH EFFECTED GROUPS AND AGENCIES}

Planning along the Providence Waterfront involves a number of interest and regulating authorities. Because of the number of special interests in the waterfront, special effort should be made to coordinate planning efforts with local neighborhood groups, State planning, the DOT, CRMC, DEM, Pawtucket, East Providence, and Cranston. Future planning efforts should reflect plans, goals and objectives from each of these effected groups.

\section{b. ANTICIPATE FUTURE DEMANDS UPON INFRASTRUCTURE}

There has been considerable time and money invested into identifying and mitigating the harbor water quality problems caused by land use and infrastructure inadequacies. Future development will continue to add to these problems. Therefore waterfront planning should include efforts to update and retrofit City's infrastructure systems to meet future demands and to ensure continued improvement to the water quality in the harbor. 
Actions should include the placement of infrastructure replacement and upgrade into the Capital Improvement Plan, establishment of erosion protection measures, and retrofitting of stormwater runnoff methods.

\section{c. IMPROVE CITY REGULATION OF WATERFRONT}

To provide for effective management, City regulatory powers should be maximized and exercised along the waterfront area. Actions should include the development of a Harbor Management Plan, improving and exercising waterfront development standards (including providing direct and indirect access to waterfront, height restrictions, and construction standards within floodplains), impact fees for upgrade of infrastructure serving new developments, considering greater standards within waterfront zones, special review of waterfront development projects (including compulsory impact assessments on large developments), greater application of the City's Capital Improvement Plan, and inclusion of waterfront goals and objectives into the City Comprehesive Plan.

\section{d. IDENTIFY INDIVIDUAL(S) WITHIN PLANNING DEPARTMENT RESPONSIBLE FOR COORDINATING WATERFRONT PLANNING.}

To facilitate planning and implementation, the coordination of waterfront planning functions should be delegated to a designated individual or small group within the Planning Department. This planning individual or small group should pursue: the development and coordination of a Waterfront Development 
Committee, the implementation of an urban impact mitigation program, the upgrading and updating of information in each study area, the integration of harbor management with waterfront plans, the identification of needed special studies, the facilitating of integrated studies and recommendations between study areas and between effected groups and agencies, and the following of implementation from the planning stages through project management department implementation.

\section{e. ENCOURAGE HISTORIC PRESERVATION}

There are many historic site along the Providence waterfront, especially within study area 3 . These historic sites are a cultural and historic resource to the City of Providence. Therefore, future waterfront planning should include historic preservation goals and objectives and continue to preserve and promote these sites as community resources.

\section{f. PROMOTE ECONOMIC DEVELOPMENT}

There are a significant number of sites available for development which can contribute to the economic development of the City. There have also been several recommendations made for City action which will contribute to the stimulation of economic development in the waterfront areas. These recommendations include: identifying new sites to attract new light industry and to encourage existing industries to expand, promoting the Port of Providence as a vital regional distribution center, preserving and enhancing shoreline areas to provide visual and pedestrian access 
to the waterfront, developing and enforcing effective design criteria for buffering residential areas from commercial areas, creating an active tourism policy and plan to promote Providence's historic and waterfront areas, promoting the use of the Seekonk River waterfront for greater water related uses, the development of a public marina, the revitalization of rail lines in the lower seekonk river section and others.

g. CONSIDER AND PURSUING ALTERNATIVE TRANSPORTATION CHOICES.

The existing transportation system serving each waterfront area and linking it to other areas is no longer adequate. Commuter, commercial and industrial traffic meet increasing resistance due to volume when moving through the areas. The result has been a corresponding increase in negative impacts on adjacent residential neighborhoods. Planning efforts should consider and recommend transportation which will improve transportation in and around the City as well as improve the overall character and image of the City. Recommended alternatives include: the development of low profile parking garages along the waterfront, the development of a miniature trolley around downtown and waterfront areas, the establishment of shuttle boats and ferries, the revitalization of the commuter shuttle train from East Providence to downtown, the improvement of roads within the port area, the extension of River Avenue to create a loop road around the east side. 


\subsection{WATERERONT IMPLEMENTATION TABLE}

To facilitate the implementation of relevent waterfront recommendations, the following table has been developed to prioritize recommendations and identify appropriate levels of involvment required by the City. Recommendations were divided into three categories: Imperitive, Needed, and Desirable. Recommendations were assigned to catagories based upon their importance in the accomplishment of waterfront goals.

\footnotetext{
Involvement Level: $\mathbf{P}=$ Policy, $\mathbf{I}=$ Implementation

Priority Ratings: $\mathbf{I}$ = Imperative, $\mathbf{N}=$ Needed, $\mathbf{D}=$ Desirable
}

City
Lnplementation
Prierity

1. Strengthen the relationship between waterfront land uses and the harbor:

a. ESTABLISH WATERFRONT ACCESS POINTS ALONG THE PROVIDENCE AND SEEKONK RIVERS . . . . . . . . . . . . . . I I N N

b. STRENGTHEN MARITIME USES OF THE

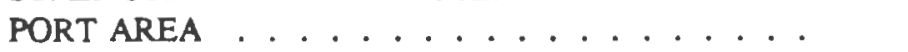

c. ESTABLISH GREATER INTEGRATION BETWEEN WATERFRONT PARKS . . . . . . I I I N

d. DEVELOP A PUBLIC MARINA(S) . . . . . . I I I D

e. PROMOTE WATER DEPENDENT/ ENHANCED COMMERCIAL USES ON THE SEEKONK RIVER ............. . P

f. ESTABLISH A PROVIDENCE HARBOR MANAGEMENT PLAN . . . . . . . . . . 
g. ESTABLISH BOAT LAUNCH ALONG

SEEKONK RIVER . . . . . . . . . .

D

2. Strengthen the land uses appropriate to each area of the waterfront:

a. REINFORCE INDUSTRIAL LAND USES WITHIN THE PORT AREA . . . . . . . . . P P/I

b. STRENGTHEN THE RESIDENTLAL CHARACTER OF THE LOWER SEEKONK

RIVER AND RIVER AVENUE SECTIONS . . . . . . P/I

c. PROMOTE MULTI-USE DEVELOPMENT IN LOWER RIVER SECTION . . . . . . . . . . . . P/I

d. ESTABLISH NEW LIGHT INDUSTRIAL DEVELOPMENT AREA .......... P $/ \mathrm{P}$

e. INCREASE PARK AREAS AND ACTIVITIES

AT INDIA PARK . . . . . . . . . . . I

f. IMPROVE ACCESS AND FACILITIES AT BLACKSTONE PARK . . . . . . . . . I I

3. Mitigate the negative impacts of development along the waterfront:

a. ESTABLISH AN URBAN IMPACT MITIGATION PROGRAM . . . . . . . . P

b. ESTABLISH AN EMERGENCY RESPONSE PROGRAM FOR THE PORT AREA . . . . . . . P

c. SUPPORT EFFORTS TO REDUCE THE LEAKAGE OF LAND USE CONTAMINANTS INTO THE PROVIDENCE HARBOR ....... I I

d. REMOVAL OF DEBRIS FROM HARBOR ...... I I N

e. IMPLEMENT PHYSICAL IMPROVEMENTS IN ALL AREAS OF THE WATERFRONT . . . . . . I

f. ESTABLISH A LOOP ROAD AROUND SEEKONK RIVER AREA . . . . . . . . I

g. MODIFY UNATTRACTIVE ASPECTS OF THE NARRAGANSET ELECTRIC FACILITIES ............ P 
h. CONSOLIDATE AND REDUCE INDUSTRIAL USES OUTSIDE PORT AREA . . . . . . . . P

$\mathbf{N}$

i. EXERCISE ENVIRONMENTAL REVIEWS

ON WATERFRONT PROJECTS . . . . . . . . . P

D

4. Provide integrated, long range

planning along the waterfront and

with the city at large:

a. COORDINATED PLANNING WITH

EFFECTED GROUPS AND AGENCIES . . . . . . P

$\mathbf{N}$

b. ANTICIPATE FUTURE DEMANDS

UPON INFRASTRUCTURE ......... P

$\mathrm{N}$

c. IMPROVE CITY REGULATION OF

WATERFRONT . . . .

d. IDENTIFY INDIVIDUAL(S) RESPONSIBLE FOR COORDINATING WATERFRONT PLANNING ............. P

e. ENCOURAGE HISTORIC PRESERVATION . . . P P D

f. PROMOTE ECONOMIC DEVELOPMENT . . . P P P

g. CONSIDER AND PURSUE ALTERNATIVE

TRANSPORTATION CHOICES ......... P 


\section{BIBLIOGRAPHY}




\section{Bibliography}

Brustline inc., Vanesse Hangen,1990. Waterfront Land Use Study.

East Providence Department of Planning, 1989. East Providence Waterfront Guideplan.

Mayors office of Community Development, 1978. Neighborhood Profiles: Providence.

Narragansett Bay Project, 1989. "Narragansett Bay Watch".

Narragansett Bay Commission. "Combined Sewer Overflow Locations in Providence".

Providence, Rhode Island, 1990. Providence Code of Ordinances.

Providence Department of Parks and Recreation. "Recreational Sites within the City of Providence", and "Existing Boat Facilities".

Providence Department of Planning and Development, 1978. 1975 Land Use Comparison.

Providence Department of Planning and Development, 1985. Old Harbor Marina Tax Increment Finance District Plan.

Providence Department of Planning and Development, 1985. "Capital Center Project, Design and Development Criteria".

Providence Department of Planning and Development, 1983. Demographic Change in Providence.

Providence Department of Planning and Development, 1990. Providence Comprehensive Plan.

Providence Historic Preservation Society, 1987. "Development and Design Guidelines for the Providence Waterfront". 
Providence Historic Preservation Society. "Properties on the National Register of Historic Places", and "List of Properties being considered for the Register".

Providence Redevelopment Agency, 1984. Port Project, Official Redevelopment Plan.

Rhode Island Department of Transportation,1989. "Field survey of traffic counts along Seekonk River".

Rhode Island Department of Environmental Management, 1988. An Assessment of Non-point Sources of Pollution to Rhode Island's Waters.

Rhode Island Coastal Resources Management Council, 1983. Coastal Resources Management Program, as amended.

Rhode Island Coastal Resources Management Council, 1984. Providence Harbor: A Special Area Management Plan.

Rhode Island Department of Environmental Management, Rhode Island Natural Heritage Program,1989. "Animal Species of Concern".

Rhode Island, 1866 - 1989. General Laws of the State of Rhode Island.

Rhode Island Department of Transportation, 1989. Traffic Circulation Study of Gano and Pitman Street Area.

Rhode Island Department of Transportation, 1982. Providence to Bristol Bicycle Facility Trip Estimates.

Rhode Island Water Resources Coordinating Board, 1959. "Groundwater Resources of the Providence Quadrangle, Bulletin no. $10 "$.

University of Rhode Island, Coastal Resources Center 1981. Providence Harbor: Problems and Perspectives.

United States Department of Agriculture, Soil Conservation Service, 1981. Soil Survey of Rhode Island. 
United States Department of Commerce, 1980. 1980 Census of Population.

United States Army Corps of Engineers, Flood Insurance Administration,1972. Flood Insurance Study.

Urban Design Group, Inc., 1975. Marinas and Pleasure Boating Facilities Study.

Warner, William, for the Providence Foundation,1985. The Providence Waterfront 1636-2000.

Winsor, David,1990. Housing Study for the City of Providence. 